\title{
Intrinsic and Extrinsic Factors Affecting Microtubule Dynamics in Normal and Cancer Cells
}

\author{
Filip Borys ${ }^{1,2, \dagger}$, Ewa Joachimiak ${ }^{1, *,+}{ }^{+}$, Hanna Krawczyk ${ }^{2}$ and Hanna Fabczak ${ }^{1, *}$ \\ 1 Laboratory of Cytoskeleton and Cilia Biology Nencki Institute of Experimental Biology of Polish Academy \\ of Sciences, 3 Pasteur Street, 02-093 Warsaw, Poland; fborys@ch.pw.edu.pl \\ 2 Department of Organic Chemistry, Faculty of Chemistry, Warsaw University of Technology, 3 Noakowskiego \\ Street, 00-664 Warsaw, Poland; hkraw@ch.pw.edu.pl \\ * Correspondence: e.joachimiak@nencki.edu.pl (E.J.); h.fabczak@nencki.edu.pl (H.F.) \\ + These authors contributed equally to this work.
}

Received: 19 June 2020; Accepted: 8 August 2020; Published: 14 August 2020

check for updates

\begin{abstract}
Microtubules (MTs), highly dynamic structures composed of $\alpha$ - and $\beta$-tubulin heterodimers, are involved in cell movement and intracellular traffic and are essential for cell division. Within the cell, MTs are not uniform as they can be composed of different tubulin isotypes that are post-translationally modified and interact with different microtubule-associated proteins (MAPs). These diverse intrinsic factors influence the dynamics of MTs. Extrinsic factors such as microtubule-targeting agents (MTAs) can also affect MT dynamics. MTAs can be divided into two main categories: microtubule-stabilizing agents (MSAs) and microtubule-destabilizing agents (MDAs). Thus, the MT skeleton is an important target for anticancer therapy. This review discusses factors that determine the microtubule dynamics in normal and cancer cells and describes microtubule-MTA interactions, highlighting the importance of tubulin isoform diversity and post-translational modifications in MTA responses and the consequences of such a phenomenon, including drug resistance development.
\end{abstract}

Keywords: $\alpha$-tubulin; $\beta$-tubulin; microtubule; post-translational modifications; cancer; microtubule-targeting agents (MTAs); tubulin-binding agents (TBAs); resistance

\section{Introduction}

Microtubules (MTs), which are dynamic cytoskeletal components, are hollow-tube filaments usually built up of 13 protofilaments composed of $\alpha$ - and $\beta$-tubulin heterodimers connected by noncovalent bonds (Figure 1). In eukaryotic cells, the initiation of tubulin polymerization, so-called nucleation, is associated with the presence of templates, including the $\gamma$-tubulin ring complex $(\gamma$-TuRC) or newly severed microtubule ends (so-called seeds) [1]. The elongation of polymerizing microtubules results in the formation of a microtubular network which is involved in many cellular processes, such as cell movement, cell shape determination, distribution of organelles, intracellular transport, and the formation of the mitotic spindle, the key structure in chromosome segregation during cell division [2,3]. Moreover, microtubules form skeletons of complex eukaryotic structures such as centrioles, basal bodies, and cilia [4]. Not surprisingly, defects in microtubule assembly or properties can lead to severe diseases, including cancer [5]. 


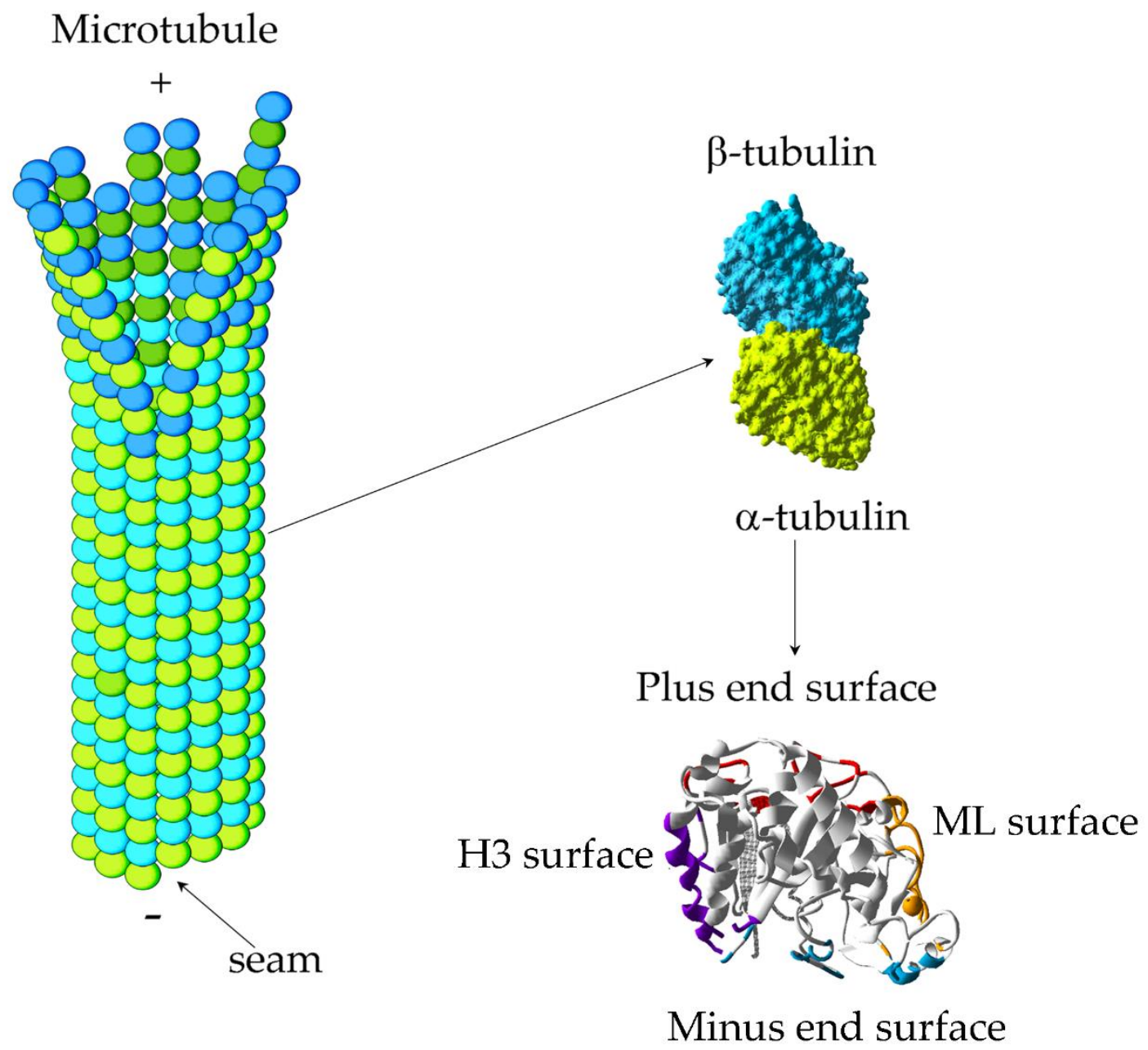

Figure 1. Scheme of the structure of microtubules, tubulin heterodimers, and functional surfaces of tubulin.

Performing such different functions requires both the stability of microtubules and the ability to quickly respond to cellular cues by shortening or directional growth. Within the cell, microtubule dynamics depends on three intrinsic factors: (i) the isotype of the incorporated $\alpha$ and $\beta$-tubulins (as in most organisms, tubulins are encoded by multiple genes) [6-10]; (ii) the type and level of post-translational tubulin modifications [11,12]; and (iii) interactions with non-tubulin proteins, so-called microtubule-associated proteins (MAPs) $[13,14]$. Besides the intrinsic factors that generate heterogeneous MTs, extrinsic physical factors (e.g., temperature) and chemical factors, so-called microtubule-targeting agents (MTAs; also known as tubulin-binding agents (TBAs), microtubule-interfering drugs, anti-microtubule drugs, or microtubule poisons) can influence MT dynamics. Taking advantage of the possibility to externally modulate MT dynamics, several microtubule-targeting agents have been employed as chemotherapeutic agents [15-17].

The effect of an individual anti-tubulin/anti-microtubule compound on the polymer mass, stability, and dynamics of microtubules is very complex. Basically, MTAs can be divided into two main categories. Compounds of the first category (microtubule-stabilizing agents (MSAs)), after binding to the tubulin heterodimer, increase the lateral interactions between heterodimers, which at high compound concentration leads to increased polymerization and stabilization of MTs, resulting in increased polymer mass within the cell. Compounds from the second group (microtubule-destabilizing agents (MDAs)) decrease or inhibit mainly longitudinal interactions between heterodimers at high concentrations, resulting in MT depolymerization and decreased polymer mass. Notably, at lower concentrations used in clinical applications, both types of MTAs only finely tune MT dynamics, with no 
effect on polymer mass or overall cytoskeleton features [16,18]. To date, six binding sites are recognized in the tubulin surface and numerous small molecules or macrocyclic compounds that alter intra- and intertubulin interactions by binding with these pockets [18].

In this review, we focus on the factors that determine microtubule dynamics in normal and cancer cells. We describe the microtubule-MTA interplay, highlighting the significance of the diversity of tubulin isoforms and their post-translational modifications in MTA response, and the consequences of this phenomenon, including the development of drug resistance. Due to the large number of chemical compounds used in cancer therapies, this paper covers only a narrow range of molecules.

\section{Structure of Tubulin: Molecular Basis of MT Dynamics}

The 3D structure of microtubule subunits was resolved in 1998 [19]. That study and subsequent studies showed that $\alpha$ - and $\beta$-tubulins share high structural similarity; both are composed of several large secondary structures, including $10 \beta$-strands (S1-S10) and $12 \alpha$-helices (H1-H12) linked by loops [19]. Additionally, six small helices (H1', H2', H2', H3', H9', and H11') are located on loops near the larger structures [20]. Helices H1-H12 and strands S1-10 constitute the protein body, which can be divided into three main domains: an N-terminal, also called a nucleotide-binding domain, a so-called intermediate domain, and a C-terminal part. The N-terminal domain (amino acids 1 to 205 ) comprises six parallel $\beta$-strands (S1-S6) alternating with $\alpha$-helices (H1-H7) linked by loops. The intermediate domain (aa 206-381) is formed by three helices (H8-H10) alternating with four $\beta$-strands (S7-S10). The C-terminal domain (aa 382 to 451 ) is composed of two $\alpha$-helices (H11-H12), followed by several unstructured amino acids that extend beyond the globular part as the so-called tubulin tail [19,20].

The nucleotide-binding and intermediate domains form the main part of the globular protein body with four distinguishable functional surfaces: plus end, minus end, H3 surface, and ML surface (Figure 1) [19,21].

The plus and minus ends of adjacent tubulins bind to each other, participating in longitudinal tubulin interactions necessary for the formation of both heterodimers and protofilaments. The minus end surface includes the amino acids of helix H10 and loops H3-S4, T7, and H10-S9 (Figure 1). The plus end is composed of residues from helices H1, H6, and H11; strand S3; and loops T3, T5, H6-H7, and H11-H12 (Figure 1). Therefore, the plus end surface also includes the nucleotide-binding pocket (NBP) where GTP/GDP is tethered (Figure 1). Importantly, the $\alpha$-tubulin plus end is tightly associated with the minus end of the $\beta$-tubulin within the heterodimer and, thus, its NBP is permanently associated with GTP (so-called non-exchangeable or N-site). Its precise function is unknown, although mutations that alter the GTP-binding site on $\alpha$ can be highly deleterious [22]. By contrast, the $\beta$-tubulin plus end, including NBP, is exposed, allowing exchange of GTP to GDP (so-called exchangeable or E-site). The GTP-bound dimer acquires a so-called curved conformation, which allows it to be accommodated at the microtubule tip. In fact, cryo-EM studies show that the microtubule tip has a slightly "open" morphology (see Figure 1) (reviewed in [18,23]). After being incorporated into a microtubule wall, a heterodimer acquires a so-called straight conformation, which requires "compression" of the $\alpha$-tubulin intermediate domain by moving S8 and S9 closer to H8 [24].

The hydrolysis of $\alpha$-tubulin-GTP causes compaction of the heterodimer and sub-nanometer shortening of the protofilament, changing longitudinal but not lateral forces within the microtubule [25]. Although GTP-to-GDP conversion is an important factor that regulates microtubule dynamics by triggering conformational changes in tubulin dimer, several studies suggest that other tubulin regions, including intermediate and C-terminal domains, could also be involved in this process [26-28].

The H3 and ML surfaces are involved in lateral interactions between heterodimers of neighboring protofilaments, leading to the arrangement of the protofilments into a cylindrical structure [19]. The H3 surface consist of helix H3 and strand S3 as well as loops H1-B1, H2-B2, and H4-S4, while the ML surface contains helices H6, H9, and H10 and loops H6-H7, S7-H9 (M-loop), and H9-S8 (Figure 1) [19].

The secondary structures of the C-terminal domain, helices H11-H12, are organized into the so-called outside of the tubulin, which in the MT, is exposed to the cytoplasm. The two helices form a 
surface on which microtubule-associated and motor proteins can bind [19,20], while the unstructured C-terminal amino acids (10 in $\alpha$-tubulin and 18 in $\beta$-tubulin) form the tubulin tail. This region is particularly variable, showing the most amino acid sequence differences between tubulin isotypes (Table 1). Such sequence divergence may provide the structural basis for the construction of specific types of microtubules and determination of their particular properties and functions [19,20].

\section{Intrinsic Factors Affecting Microtubule Dynamics}

\subsection{Tubulin Isotypes and Microtubule Dynamics}

The human genome encodes seven $\alpha$ - and nine $\beta$-tubulin isotypes [29]. As a consequence, MTs composed of mixed combinations of $\alpha$ - and $\beta$-tubulin isotypes show tissue and developmental stage specificity and different properties in different cell types [30,31].

Human $\alpha$-tubulins belongs to four classes (out of nine characterized in mammals; see [32,33]): $\alpha \mathrm{I}$ (isotypes $\alpha \mathrm{Ia}$ and $\alpha \mathrm{Ib}$ ), $\alpha \mathrm{III}, \alpha \mathrm{IV}$ (isotypes $\alpha \mathrm{IVa}$ and $\alpha \mathrm{IVb}$ ), and $\alpha \mathrm{VIII}$ (Table 1). Interestingly, two classes show tissue-specific distribution, with $\alpha$ III restricted mainly to testis and $\alpha$ VIII to heart and skeletal muscle, while the other two are widely distributed [34-39]. Although the tissue or cell type-specific functions of $\alpha$-tubulin isotypes were only recently addressed for several isotypes ( $\alpha$ Ia in neuron migration [40], $\alpha$ IVa in platelets [41], and $\alpha \mathrm{VIII}$ in brain and testis [42]), the role of $\alpha$-tubulin isotypes in MT dynamics remains unknown.

Human $\beta$-tubulins belong to seven classes (out of nine in mammals): I-VI and VIII (Table 1). From published data and the publicly available National Center for Biotechnology Information (NCBI) database, it seems that the most ubiquitously expressed isotypes are $\beta \mathrm{I}, \beta \mathrm{IVb}, \beta \mathrm{V}$, and $\beta \mathrm{VIII}$, while other $\beta$-tubulins have more specific tissue distribution (Table 1) [43]. Interestingly, although they are widely distributed, $\beta \mathrm{I}, \beta \mathrm{V}$, and $\beta$ VIII were shown to have nonredundant roles in specific cellular or developmental processes. The silencing of $\beta I$ expression in differentiating human neuroblastoma cells was lethal, while depletion of $\beta I$ in undifferentiated cells had no apparent effect on cell survival [44]. On the other hand, $\beta$ VIII is essential for oocyte maturation and early embryo development [45].

$\beta I I, \beta I I I$, and $\beta$ IVa are mainly expressed in the brain (Table 1$)[43,46,47]$. Accordingly, experimental data indicate their specific role in processes related to the nervous system. The silencing of $\beta$ II inhibits neurite outgrowth in differentiating neuroblastoma cells, while $\beta$ III was suggested to protect cells against oxidative stress [44]. However, more recent data with the use of Tubb3 knockout mice indicate that the $\beta$ III isotype functions in the process of axon growth and nerve regeneration [48]. An interesting observation was made for $\beta$ IVa: mutations in this tubulin can cause dysfunction of neurons, oligodendrocytes, or both [49].

Not much is known about the functions of other $\beta$-tubulin isotypes, $\beta \mathrm{IVb}$ and $\beta \mathrm{VI}$. The latter shows slightly higher expression in bone marrow (Table 1) and is essential for the formation of platelet cytoskeleton (reviewed in [50]); in many publications, the TUBB1 gene product, following protein names in the database, is called $\beta 1$ or $\beta-1$ instead of $\beta \mathrm{VI})$.

How do particular $\alpha$ - and $\beta$-tubulin isotypes relate to MT dynamics? The answer to this question came from studies focusing mainly on the comparison of the properties of three neuronal isotypes, $\beta$ II, $\beta$ III, and $\beta$ IV. The molecular surfaces of tubulins are very similar, considering the level of amino acid similarity, which for $\alpha$-tubulins reaches approximately $90-95 \%$, and is slightly lower for $\beta$-tubulins at $\sim 85-95 \%$ (with $\beta$ VI being the most divergent, with approximately $75 \%$ similarity to other isotypes). Most amino acid substitutions are accumulated within the C-terminal tubulin tail (Table 1), suggesting that this part could be responsible for the potential variation of properties of tubulin isotypes and, subsequently, the differences in MT dynamics [29]. However, several $\beta$ isotypes also have unique substitutions in other regions important for the formation of functional surfaces and pockets. 
Table 1. Features of human tubulin isotypes.

\begin{tabular}{|c|c|c|c|c|c|}
\hline $\begin{array}{l}\text { Tubulin } \\
\text { Isotype }\end{array}$ & Gene Name & Expression & $\begin{array}{c}\text { Cell } \\
\text { Type-Specific } \\
\text { Functions }\end{array}$ & $\begin{array}{l}\text { Sequence of } \\
\text { C-Terminus * }\end{array}$ & Reference \\
\hline$\alpha \mathrm{Ia}$ & ТUВA1A & ubiquitous & $\begin{array}{c}\text { neuron } \\
\text { migration }\end{array}$ & VEGEGEEEGEEY & {$[40,51]$} \\
\hline$\alpha \mathrm{Ib}$ & ТUВA1B & ubiquitous & & VEGEGEEEGEEY & [52] \\
\hline$\alpha \mathrm{Ic}$ & ТUВA1C & ubiquitous & & ADGEDEGEEY & [53] \\
\hline$\alpha \mathrm{III} \mathrm{c}$ & ТUВАЗС & testis & & VEAEAEEGEEY & [54] \\
\hline$\alpha \mathrm{III}$ & TUBAЗE & testis & & VEAEAEEGEAY & [55] \\
\hline$\alpha \mathrm{IVa}$ & ТUВA4A & ubiquitous & $\begin{array}{c}\text { platelet } \\
\text { biogenesis }\end{array}$ & YEDEDEGEE & {$[41,56]$} \\
\hline$\alpha \mathrm{VIII}$ & TUBA8 & $\begin{array}{l}\text { high: heart and } \\
\text { skeletal muscle } \\
\text { moderate: brain, } \\
\text { testis, and thyroid } \\
\text { very low: all other } \\
\text { tissues }\end{array}$ & spermatogenesis & FEEENEGEEF & {$[35,42,57]$} \\
\hline$\beta I$ & ТUВВ & ubiquitous & $\begin{array}{c}\text { survival of } \\
\text { differentiated } \\
\text { neuroblastoma }\end{array}$ & EEEEDFGEEAEEEA & {$[43,44,58]$} \\
\hline$\beta$ ІІІа & ТUВВ2A & $\begin{array}{l}\text { high: brain } \\
\text { very low: all other } \\
\text { tissues }\end{array}$ & $\begin{array}{c}\text { neurite } \\
\text { outgrowth }\end{array}$ & DEQGEFEEEEGEDEA & {$[43,44,59]$} \\
\hline$\beta I I b$ & ТИВВ2В & $\begin{array}{l}\text { high: brain } \\
\text { very low: all other } \\
\text { tissues }\end{array}$ & $\begin{array}{c}\text { neurite } \\
\text { outgrowth }\end{array}$ & DEQGEFEEEEGEDEA & {$[43,44,60]$} \\
\hline$\beta \mathrm{III}$ & TUBВ3 & $\begin{array}{l}\text { moderate: brain } \\
\text { low: testis }\end{array}$ & $\begin{array}{l}\text { oxidative stress } \\
\text { axon and nerve } \\
\text { regeneration }\end{array}$ & EEEGEMYEDDEEEESEAQGPK & {$[43,44,48,61]$} \\
\hline$\beta I V a$ & ТUВB4A & $\begin{array}{c}\text { high: brain } \\
\text { moderate/low: other } \\
\text { tissues } \\
\text { ubiquitously }\end{array}$ & $\begin{array}{l}\text { neurons and } \\
\text { oligodendrocyte } \\
\text { function }\end{array}$ & EEGEFEEEAEEEVA & {$[43,49,62]$} \\
\hline$\beta \mathrm{IVb}$ & $\begin{array}{l}\text { TUBB4B/ } \\
\text { TUBB2C }\end{array}$ & $\begin{array}{l}\text { high: testis, bone } \\
\text { marrow, and heart } \\
\text { moderate/low: other } \\
\text { tissues }\end{array}$ & & EEEGEFEEEAEEEVA & {$[43,63]$} \\
\hline$\beta \mathrm{V}$ & ТUВВ6 & $\begin{array}{l}\text { ubiquitous at low } \\
\text { levels }\end{array}$ & $\begin{array}{l}\text { related to } \\
\text { skeletal muscle } \\
\text { regeneration }\end{array}$ & NDGEEAFEDEEEEIDG & {$[43,64,65]$} \\
\hline$\beta \mathrm{VI}$ & ТUВВ1 & $\begin{array}{l}\text { very low level in all } \\
\text { tissues, highest in } \\
\text { bone marrow and } \\
\text { spleen }\end{array}$ & $\begin{array}{c}\text { platelet } \\
\text { cytoskeleton }\end{array}$ & VLEEDEEVTEEAEMEPEDKGH & {$[43,66]$} \\
\hline$\beta$ VIII & TUBB8 & $\begin{array}{l}\text { very low in all } \\
\text { tissues, highest in } \\
\text { testis }\end{array}$ & $\begin{array}{c}\text { oocyte } \\
\text { maturation, } \\
\text { early } \\
\text { development }\end{array}$ & EEEEDEEYAEEEEVA & [67] \\
\hline
\end{tabular}

Blue: negatively charged amino acids, red: positively charged amino acids, yellow: C-terminal tyrosine residue, purple: phosphorylatable residue, * sequences were taken from the NCBI database.

Among the investigated $\beta$-tubulin isotypes ( $\beta I I, \beta I I I$, and $\beta I V), \beta I I I$ is the most divergent, with substitutions in globular protein body including: (i) helix H3 (serine in positions 124 and 126 is substituted by cysteine and asparagine, respectively), (ii) loops H1-S2 and H2-S3 (structures involved in the formation of H3 surface), (iii) structures located proximal to the ML surface (H6-H7 loop threonine 217 and S7-H9 loop serine 275 substituted to alanine) [68], and (iv) T7 loop (minus end surface) near colchicine-binding site (cysteine 239 substituted by serine). Moreover, the C-terminal tail of $\beta \mathrm{III}$ is very divergent. It contains positively charged lysine (Table 1) and a phosphorylatable serine $[69,70]$. These variations are potentially important for the overall tubulin structure; in fact, an atomic model of $\beta$ III-containing MTs shows slight but significant displacement of the H1-S2 loop and part of the ML surface-forming structures with respect to $\beta$ II-containing MTs [68]. However, how $\beta$ III substitution relates to its specific properties is mainly unknown.

For more than two decades, it has been known that MTs assembled from $\beta$ III tubulin are more dynamic than MTs containing $\beta$ II or $\beta$ IV [9]. More recent data indicate that the main difference is caused by the significantly increased catastrophe rate (depolymerization) of $\beta$ III-containing MTs [27,71,72], 
while the growth rate seems to be similar [27,71] or only slightly lower [72]. The dynamic features of MTs assembled with specific isotypes were retained when the C-terminal tails of $\beta$ II and $\beta$ III were interchanged, indicating that the dynamic properties of these two tubulins are "encoded" within the main globular protein body [71]. Remarkably, not only dynamics, but also resistance to depolymerizing factors and structural features vary between $\beta$ II- and $\beta$ III-containing MTs, with the former showing lower resistance to depolymerizing agents and more protofilaments in the MT wall (14) than the latter ( $\beta$ III contains 13 protofilaments and shows more resistance to depolymerizing factors) [68]. Interestingly, when two populations of tubulin heterodimers are mixed with different stoichiometry, assembled MTs show intermediate dynamics [68,71,72].

On the other hand, at low tubulin concentration, the MTs nucleate much more slowly if the tubulin heterodimers contain $\beta$ III-tubulin compared to $\beta \mathrm{II}$ or $\beta \mathrm{IV}$. Interestingly, this difference can be abolished by the proteolytic removal of C-terminal tail [8]. This result indicates that although it is not crucial for dynamic tubulin properties, the tubulin C-terminus can influence other features that could be important for MT cytoskeleton formation within the cell.

To summarize, growing evidence indicates that the intrinsic properties of tubulin isotypes, the expression of specific isotypes, and their ratio within the cell are significant factors influencing MT dynamics.

\subsection{Post-Translational Modifications of Microtubules}

Tubulin modification sites, modifying enzymes, and functions of post-translational modifications (PTMs), including the impact on MT dynamics, have recently been broadly reviewed $[12,33,73,74]$. Thus, here, we will only briefly summarize how PTMs affect MT dynamics.

Both $\alpha$ - and $\beta$-tubulin undergo a number of post-translational modifications that change the properties of the free tubulin heterodimers and microtubules. Tubulin PTMs can modulate MT dynamics directly or indirectly by influencing the interactions between MTs and microtubule-interacting proteins (which can stabilize, destabilize, or cut microtubules).

While for the vast majority of modifying enzymes, a tubulin heterodimer already incorporated into the microtubule lattice is a preferred substrate, in some cases, free tubulin heterodimers are effectively modified. The latter can affect the binding of tubulin heterodimers to the microtubule plus end and, thus, affect microtubule growth and stability. For instance, acetylation of lysine 252 of $\beta$-tubulin by San acetyltransferase slows down the rate of tubulin incorporation into the microtubule and consequently reduces the rate of MT assembly [75]. Phosphorylation of serine 172 of $\beta$-tubulin by minikinase/DYRK1a (neurons) or cyclin-dependent kinase Cdk1 (mammalian mitotic cells) inhibits the incorporation of tubulin heterodimers [76,77], while heterodimers containing $\alpha$ Ic-tubulin phosphorylated at serine 165 assemble more effectively than unmodified ones [78,79]. Serine and threonine residues of $\alpha$ - and $\beta$-tubulin can also be modified by $O$-Glc-NAcylation $[80,81]$ and, in vitro, such modified tubulins are not incorporated into microtubules [81].

The presence of differentially modified MTs within the cell is crucial in the assembly, disassembly, and rearrangement of the microtubular cytoskeleton [82]. Newly polymerized dynamic microtubules are highly tyrosinated (besided $\alpha \mathrm{IVa}$, tyrosine is encoded in the C-terminus of $\alpha$-tubulins, see Table 1 ). With time, the tyrosine is removed by the vasohibin family, VASH1 and VASH2 tubulin detyrosinases, generating so-called detyrosinated tubulin. Detyrosinated tubulin is found in spindle and is essential for correct chromosome congression [83]. Glutamic acid residue, which is the most frequent penultimate residue in $\alpha$-tubulin, can also be removed by cytosolic carboxypeptidases, irreversibly forming so-called $\Delta 2$-tubulin [84-87]. After depolymerization, free detyrosinated $\alpha$-tubulin can be re-tyrosinated by tubulin tyrosine ligase (TTL) $[88,89]$.

The $\alpha$-tubulins I, II, III, IV, and VII have a lysine at position 40. Acetylation of lysine 40 residue by $\alpha$-tubulin $\mathrm{N}$-acetyltransferase 1 (ATAT1) has been known to mark stable microtubules [90-93]. The modification is reversible, and tubulin deacetylation is carried out by histone deacetylase 6 (HDAC6) [94] and Sirt2 deacetylase [95]. Recent analysis using high-resolution cryo-electron microscopy 
showed that the acetylation of lysine 40 restricts the range of motion of the loop containing K40, likely weakening the lateral contacts between protofilaments [96] and thus increasing MT flexibility $[97,98]$.

Polyamination of $\alpha$ - and $\beta$-tubulin by a transglutaminase causes the formation of hyperstable, cold-resistant microtubules. This modification is important for neuronal development and axon maturation [99]. The positions of the main polyamination sites near the GTP pocket (glutamine 15 in $\beta$-tubulin) and $\alpha$-tubulin minus end suggest that tubulin polyamination could affect GTP binding or hydrolysis and microtubule lattice stabilization [99].

Glycylation and glutamylation of $\alpha$ - and $\beta$-tubulin can occur as mono- or polymodification, and glycyl or glutamyl residues are ligated to the glutamic acid residues within the C-terminal tail [73,92]. These tubulin modifications are catalyzed by enzymes related to TTL, called tubulin tyrosine ligase-like (TTLL) [73]. The reverse reaction (deglutamylation) is carried out by cytoplasmic carboxypeptidases (CCPs). To date, the identity of tubulin deglycylase remains unknown [92].

\subsection{Microtubule-Associated Proteins and Microtubule Dynamics}

Microtubule-associated proteins (MAPs) are another intrinsic factor affecting microtubule dynamics (reviewed in [100-102]). Generally, MAPs function as MT stabilizers or destabilizers; however, stabilization/destabilization of MTs can be achieved by affecting one of several processes, including MT nucleation [1] and stabilization/destabilization of the MT ends [2] or of the MT lattice [102,103]. For this reason, MAPs are divided into several functional categories: (i) microtubule nucleators, (ii) MT end-binding proteins, (iii) lattice-binding proteins also known as structural MAPs, (iv) enzymes severing or depolymerizing microtubules, and (v) motor MAPs (kinesin, dynein) that generate forces and use microtubules as tracks for intracellular transport [102]. Intriguingly, some MAPs can participate in several MT dynamics-related processes. For example, XMAP215 can be classified as both an MT nucleator and a plus end-binding protein [1,2] while kinesin-13 family proteins are motor proteins that bind to microtubule plus ends and have MT-depolymerizing properties $[104,105]$. Because MAPs form a large class of proteins and a number of high-quality reviews on this topic are already available, we will only provide a short overview of these proteins, highlighting the relationship between MAPs and MT dynamics.

Microtubule nucleators enhance the initiation of MT formation from both $\gamma$-TuRCs and microtubule seeds and stabilize growing MTs. This category of MAPs includes XMAP215/CKAP5, TPX2 (targeting factor for Xklp2), DCX (doublecortin), CAMSAP (calmodulin-regulated spectrin-associated protein)/Patronin, CLASP (cytoplasmic linker associated protein), and p150Glued proteins [1,23]. They are believed to act mainly as enhancers of longitudinal and lateral contacts between tubulin dimers [1]. Interestingly, TPX2, besides its nucleating activity, also suppresses MT depolymerization and shrinkage, and thus increases MT stability [106].

Proteins that bind to MT ends are specific to either the plus (so-called +TIPs [107]) or minus end (so-called -TIPs [108]). Plus TIPs belong to approximately 20 different families of proteins [107]. EB (end-binding) proteins form a core of +TIP network and the majority of studies suggest that they stabilize or protect the MT plus end [107]. EB proteins interact with both the MT plus end and other + TIP proteins that can be either stabilizers (as CLIP-170 (cytoplasmic linker protein 170)/CLIP1 and CLASP proteins), destabilizers (as kinesin-13 family proteins), or polymerases (as XMAP215 protein). Within the cell, the interplay between these proteins results in MT growth or shrinkage (reviewed in $[2,23,107])$.

Stathmin-1, also known as Op18 (oncoprotein 18), binds to the MT plus end but is not included in the +TIP protein class. It was first discovered as an oncoprotein highly expressed in some types of leukemia, breast, and ovarian cancers [109]. Stathmin-1 causes a decrease of the MT polymer mass by two mechanisms: (i) by binding two tubulin dimers in a curved conformation and inhibition of their incorporation into microtubule and (ii) by interfering with the lateral bonding between tubulin subunits, leading to destabilization of the microtubule tip and MT shrinkage [110,111]. 
A recently described class of -TIP, includes CAMSAP proteins and the KANSL complex [108]. In mammals, CAMSAP proteins protect the MT minus end against the depolymerizing activity of kinesin-13. Additionally, CAMSAP2 and 3 proteins decrease the rate of tubulin incorporation at the minus end, decreasing its dynamics [112]. The functions of KANSL complex are still unknown [108].

The lattice-binding MAPs include classical MAPs, MAP1, MAP2, MAP4, MAP6, MAP7, and Tau, which promote polymerization, stabilization, and bundling of microtubules (reviewed in [102]). They also regulate the association of MTs with other cytoskeletal fibers, organelles, and membranes, and influence the ratio of transport along MTs and MT severing by physically blocking the access of motors and severing enzymes. Additionally, structural MAPs can regulate the number of MT protofilaments [102]. Interestingly, it seems that MAP6 has unique properties and functions as it is a microtubule luminal protein and protects MTs against drug and cold-dependent destabilization [113]. With the exception of MAP4, which is a ubiquitous protein, and the expression of MAP7 in epithelial cells, the expression of structural MAPs is mainly restricted to the brain [114].

Microtubule organization is also regulated through the microtubule-severing proteins katanin, spastin, and fidgetin, whose activity can lead to MT shortening or even depolymerization, but also to the formation of numerous microtubule seeds that serve as MT nucleation templates and free tubulin dimers that can be incorporated into new microtubules. Therefore, severing activity can have both a negative and positive effect on MT dynamics and microtubule polymer mass (reviewed in [103]).

It should be noted that, within a cell, the organization and dynamics of MTs is a result of the interplay between tubulin isotypes, their posttranslational modifications, and microtubule-associated proteins. For example, tyrosination increases the affinity of MT to the stabilizing protein, CLIP-170/CLIP-1 but, also to depolymerizing proteins from the kinesin-13 family [115-117]. Similarly, tubulin polyglutamylation affects the interactions of MT with several MAPs, including Tau, MAP1, and MAP2, but also with MT-severing proteins [118-120].

\section{Extrinsic Factors Affecting Microtubule Dynamics}

\subsection{Microtubule-Targeting Agents}

The surface of the globular part of tubulins contains several pockets that can be intercalation sites for MTAs. These compounds, while embedded in the tubulin structure, can alter the microtubule dynamics. This feature of MTAs is used in cancer therapy, as it was shown that treatment of cancer cells with MTAs led to the mitotic arrest and consequent cell death $[18,121]$. Many MTA compounds are produced by plants, fungi, and invertebrates as a natural defense against antagonists, competitors, or parasites (for a review, see [122]).

Currently, six MTA-binding sites, named after the main compounds with affinity to them, have beem described (Figure 2). Four pockets are located on $\beta$-tubulin: taxane, laulimalide/peloruside, vinca, and maytansine sites. The colchicine site is islocated near the intradimer interface between the $\alpha$ - and $\beta$-tubulin subunits, while the pironetin site is a binding pocket located on the $\alpha$-tubulin surface (for a review, see [18]). Taxane and laulimalide/peloruside sites bind compounds that stabilize microtubules (MSAs), while the other four pockets accommodate factors that destabilize MTs (MDAs). 
MSAs

MDAs

Maytansine-site ligands

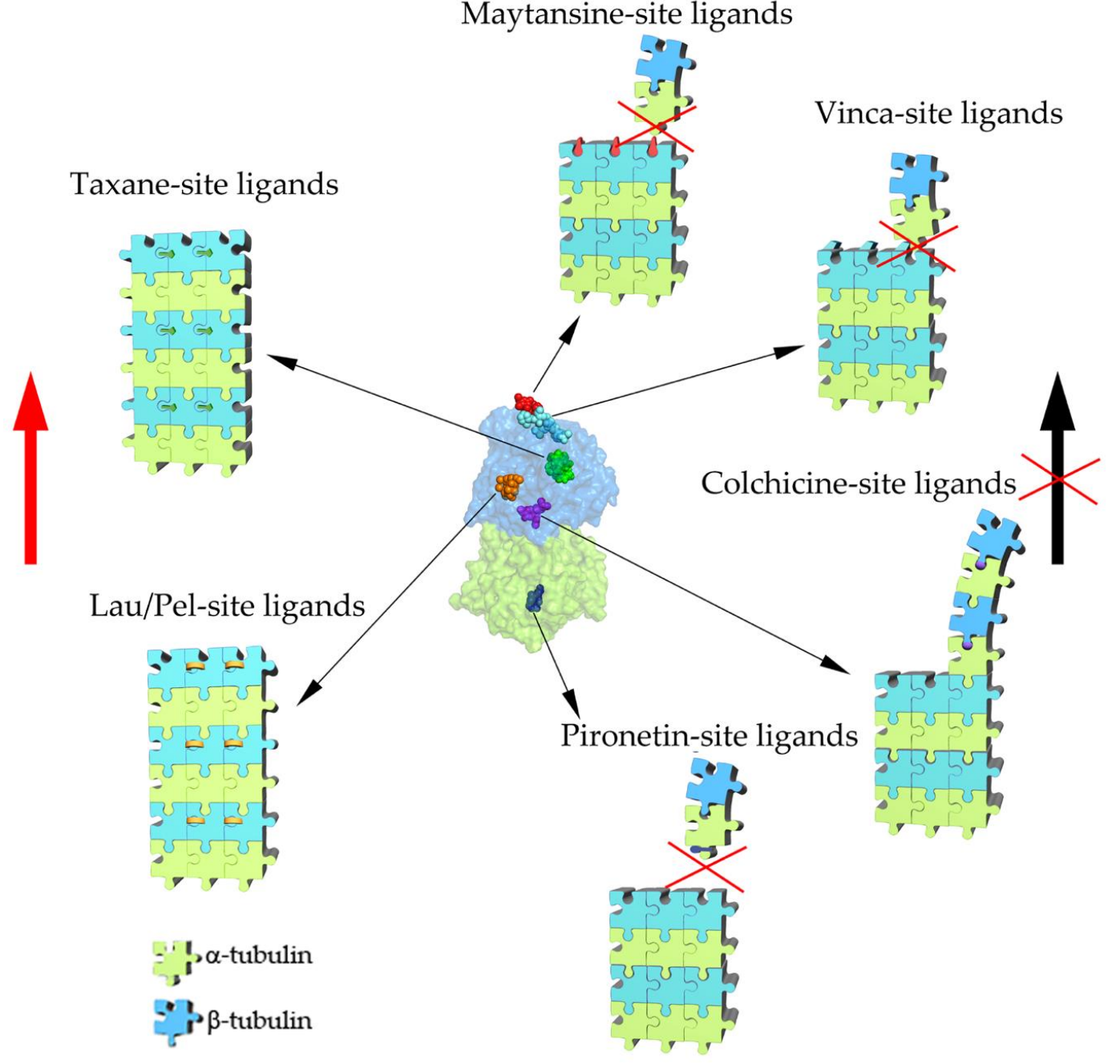

Figure 2. Location of the microtubule-targeting agent (MTA)-binding site on tubulin and the MTA mechanism of action. Microtubule-stabilizing agents (MSAs) (taxane and laulimalide/peloruside-site ligands) promote microtubule (MT) growth (red arrow) by stabilizing lateral contacts between neighboring heterodimers (see text). MDAs inhibit MT growth and destabilize MTs (crossed out black arrow) by inhibiting addition of new heterodimers at the MT plus end (maytansine- and pironetin-site ligands) or by inhibiting transition of heterodimer structure to straight conformation (colchicine- and vinca-site ligands) (see text).

\subsection{Tubulin Pockets}

\subsubsection{Taxane Site}

Paclitaxel, a tetracyclic diterpenoid originally isolated from Taxus brevifolia in the 1960s [123], was approved for the treatment of ovarian cancer in 1992 by the US Food and Drug Administration (FDA) as Taxol ${ }^{\circledR}$. Now, paclitaxel is produced by a semi-synthetic route by modifying 10 -deacetylbaccatins III derived from the European yew Taxus baccata [124].

Paclitaxel and its derivates are used in diverse cancer therapies and are characterized by high neurotoxicity, myelosuppression, poor water solubility, and the occurrence of multidrug resistance (MDR) in treated tumors (see below). This led to the search for and discovery of other compounds that enhance microtubule stabilization, including epothilones A, B, and D; discodermolide (DDM) and the 
DDM-paclitaxel hybrid KS-1-199-32; dictyostatin; taccalonolide A and J; and zampanolide (Figure 3) (for reviews, see $[18,125,126])$.

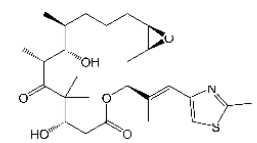

Epithilone A

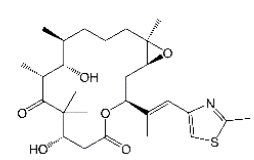

Epithilone B

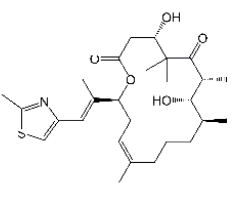

Epithilone D

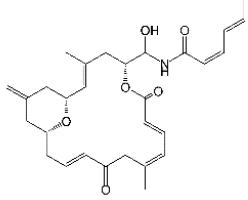

Zampanolide

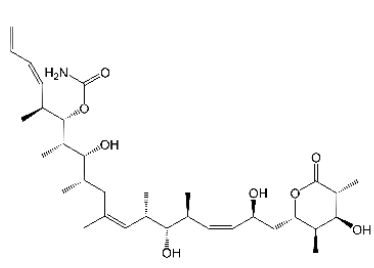

Discodermolide

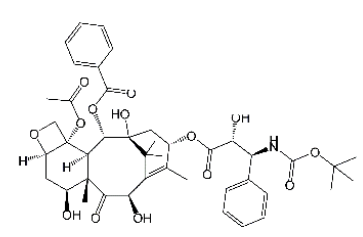

Docetaxel

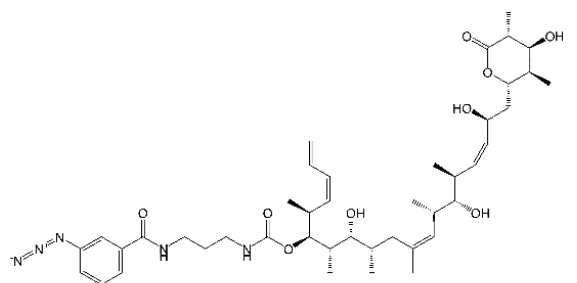

Discodermolide hybrid - KS-1-199-32

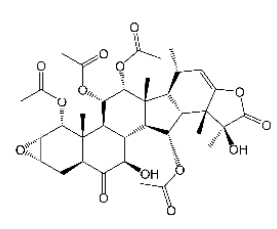

Taccalonolide A

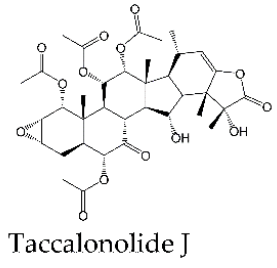

Taccalonolide J
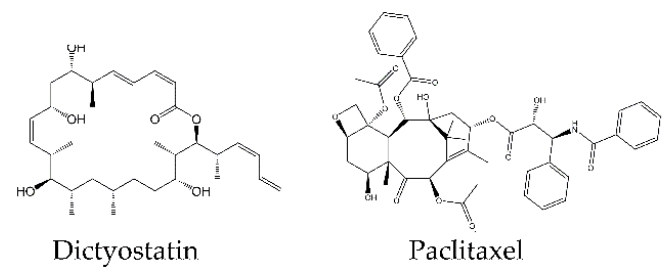

Figure 3. Structure of docetaxel; epothilones A, B, and D; discodermolide (DDM), KS-1-199-32; dictyostatin; taccalonolide A and J; zampanolide; and paclitaxel.

Epothilones A and B are macrolide drugs (natural products that consist of a large macrocyclic lactone ring) produced by the myxobacterium Sorangium cellulosum [127]. Unlike paclitaxel, they are highly soluble in water and are not a substrate for P-glycoprotein, which actively transports drugs out of the cell. A semi-synthetic derivate of epothilone B, ixabepilone, was approved for cancer treatment $[128,129]$.

Zampanolide, a sponge-derived macrolide, and taccalonolide A and J, polycyclic steroids isolated from plants of the genus Tacca, were more recently discovered and are still under investigation, but are promising antitumor drug candidates [130]. They both have the unique ability to bind covalently to taxane-site residues asparagine 228/histidine 229 and aspartic acid 226 [130,131].

Taxane-site targets are used in the treatment of various cancers, including ovarian (paclitaxel), breast (paclitaxel, docetaxel, larotaxel, ixabepilone), lung (docetaxel, epothilone B, larotaxel), bladder (larotaxel), hormone-resistant prostate cancer (cabazitaxel), and others [128,129,132-137].

The taxane (Figure 2) site is located near the ML surface, on the "inside" side of the tubulin (which in MT, faces the lumen), and is formed by hydrophobic residues of H7, S7, and loops H6-H7, S7-H9 (M loop), and S9-S10 (Figure 2) $[19,20,138]$. All compounds (Figure 3) that bind to the taxane site form hydrophobic and polar contacts with pocket amino acids and strengthen the lateral contacts between heterodimers of adjacent protofilaments, leading to MT stabilization (Figure 2). The mechanism of microtubule stabilization is compound-specific $[25,131,138,139]$. Several compounds that contain side chains, such as epothilone A and zampanolide, engage with the M loop, stabilizing it into a short helix [138]. Significantly, a similar helical conformation of the M loop was observed in native polymerized MTs $[25,138]$, indicating its importance in the formation of stable MT. Other compounds (e.g., taccalonolide A and J) cause displacement of the M-loop into a more open conformation, facilitating lateral interactions between adjacent protofilaments [131]. By contrast, paclitaxel was suggested to stabilize MTs via an allosteric mechanism by preventing dimer compaction after GTP 
hydrolysis [25,138]. A similar indirect effect was also proposed as an additional mechanism of MT stabilization for taccalonolide AJ and zampanolide [130,131].

\subsubsection{Laulimalide/Peloruside Site}

Laulimalide and peloruside A (Figure 4), macrolides originally isolated from marine sponges (Cacospongia mycofijiensis and Mycale hentscheli, respectively) [140-142], are promising non-taxane-site MSAs. Although high-resolution X-ray crystallography and cryo-EM have resolved the tubulin-compound interactions in detail $[138,143]$, biological investigation of these MTAs is still ongoing [144-146].

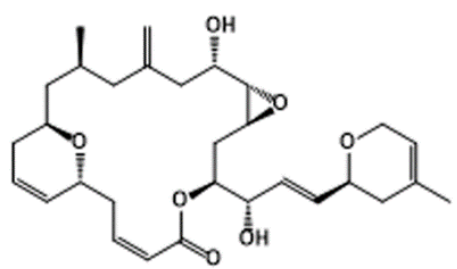

Laulimalide

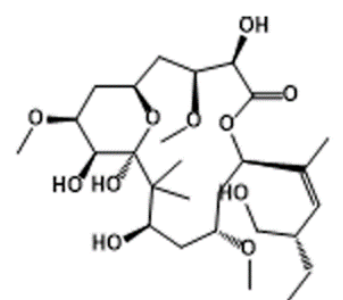

(-) - Peroluside A

Figure 4. Structure of laulimalide and peloruside A.

The laulimalide/peloruside site is positioned at the opposite side of the ML surface with respect to the taxane site, i.e., the "outside" surface of the MT wall (Figure 2), and is formed by hydrophobic and polar residues of H9 (including a short loop that divides H9 into H9 and H9'), H10, and loop H10-S9 of $\beta$-tubulin (Figure 2) [138,143].

After binding laulimalide or peloruside to the $\beta$-tubulin pocket, MTs are stabilized by two main mechanisms which strengthen the lateral contacts between neighboring protofilaments. First, the $\beta$-tubulin $\mathrm{M}$ loop shifts to an "open" conformation (without forming the regular secondary structure). Second, the position of both agents within the pocket allows their interaction with the $\mathrm{H} 3$ surface of the adjacent heterodimer, which leads to bridging of neighboring protofilaments (Figure 2) [143]. In the case of peloruside A, an especially strong effect is observed in the seam, where the lateral contacts are weaker. It was also proposed that both compounds fix structures located near the M loop and, thus, have an additional allosteric effect on MT stabilization [143].

\subsubsection{Vinca Site}

The naturally occurring vinca alkaloids (vincristine and vinblastine) were discovered in periwinkle (Catharantus roseus G. Don.) in the late 1950s (Figure 5). These are first-generation vinca alkaloids that have achieved significant clinical progress $[147,148]$. The therapeutic success of vinca alkaloids in the treatment of hematological cancers (mainly childhood leukemia) [149] led to the development of diverse semi-synthetic analogs (Figure 5) [150], including vindesine, vinorelbine, and vinflunine, the latter used for the treatment of solid tumors, particularly metastatic breast cancer [151]. However, similar to taxanes, vinca alkaloids have severe side effects (peripheral neuropathies and reversible myelosuppression) [152,153]. 


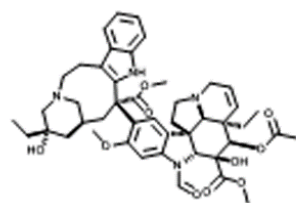

Vincristine

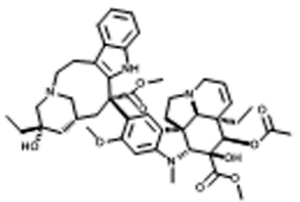

Vinblastine

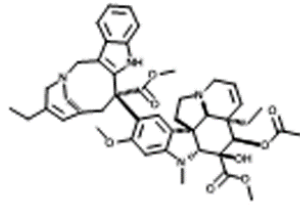

Vinorelbine

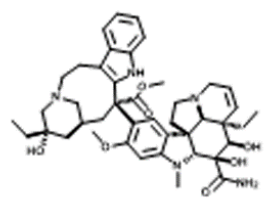

Vindesine

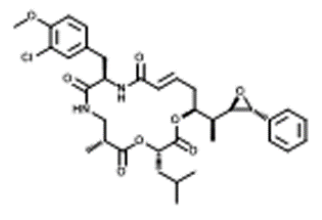

Crypthophycin 1

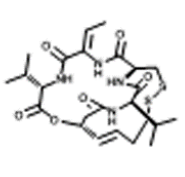

Romidepsin/ FK-228

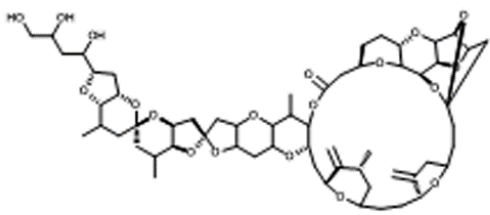

Halichondrin B

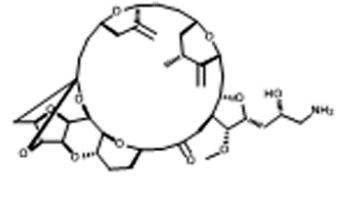

Erilubin/E-7389

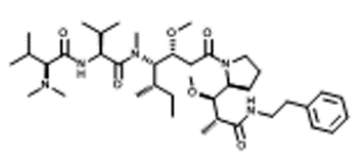

Soblidotin/TZT-1027

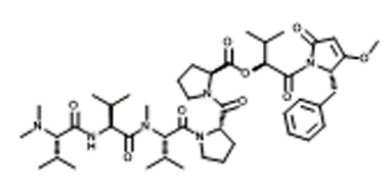

Dolastin 15

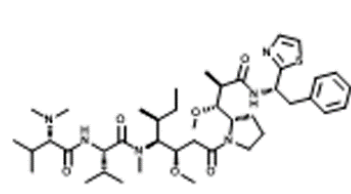

Dolastin 10

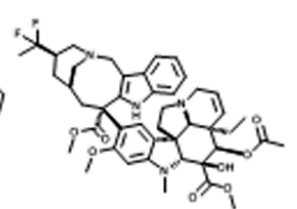

Vinflunine

Figure 5. Structure of vincristine, vinblastine, vindesine, vinorelbine, vinflunine, dolastatin-10, dolastatin-15, TZT-1027, cryptophycin 1, FK228, halichondrin B, and E-7389.

Besides vinca alkaloids, several other groups of compounds were also shown to target the vinca site, including peptides, depsipeptides, and macrolides, and some have been used in clinical trials (reviewed in $[18,125,154,155])$. Currently, vincristine and vinblastine are used for the treatment of breast cancer, lymphomas, and sarcomas [150], vinorelbine for breast and lung cancer, sarcomas, and glioma [150,156], vindesine for lung cancer [150], vinflunine for urothelial cancer [157,158], vintafolide (vinflunine and folate) for lung, ovarian, and endometrial cancer [159], eribulin for liposarcomas, bladder cancer, and metastatic breast cancer $[160,161]$, and dolastatin 10 for solid tumors [162].

The vinca site is located at the plus end surface of $\beta$-tubulin and is formed by residues of $\mathrm{H} 6$ and loops $\mathrm{T} 5$ and $\mathrm{H} 6-\mathrm{H} 7$; however, several agents also bind to $\mathrm{H} 7$ and $\beta$-tubulin-bound nucleotide sites [163-165]. The vinca-site ligands also form connections with $\alpha$-tubulin of the subsequent dimer, interacting with its minus end surface structures, including H10, S9, and T7 loop [163].

The binding of ligands to the vinca site alter the surface of the $\beta$-tubulin plus end, forming a so-called wedge (Figure 2) [163], thus interfering with the incorporation of new heterodimers at the MT plus end. As a result, the plus end heterodimers remain in curved conformation, which inhibits formation of the MT wall and leads to destabilization [163]. It was also shown that vinca-site ligands can cause the formation of ring-like tubulin oligomers, decreasing the level of free tubulin available for polymerization (Figure 2) $[163,166]$. Additionally, several vinca-site compounds were shown to have an allosteric effect on the inhibition of lateral contacts between dimers by stabilizing the M loop in the interaction-incompetent conformation [165].

\subsubsection{Maytansine Site}

Maytansine and its derivatives were first isolated from an African shrub, Maytenus ovatus [167]. They belong to the natural product group of maytansinoids, macrolides of the ansamycin type (Figure 6). Later, other groups of compounds, including macrocyclic polyketides (disorazole Z, Figure 6), macrocyclic lactones (rhizoxin, Figure 6), lactones (plocabulin, PM060184, Figure 6), and macrocyclic lactone polyethers (spongistatin 1, Figure 6) were isolated. 
It is worth noting that PM060184 is currently under clinical evaluation [168], while ado-trastuzumab emtansine was recently approved for adjuvant treatment of patients with HER2-positive early breast cancer [169] and was shown to prolong patient survival with a manageable safety profile [170].

The maytansine site is located in close vicinity to NBP and the vinca site, but is formed by other structures, including H3', H11, H11', and loops H11-H11', T3, and T5 (Figure 2) [171].
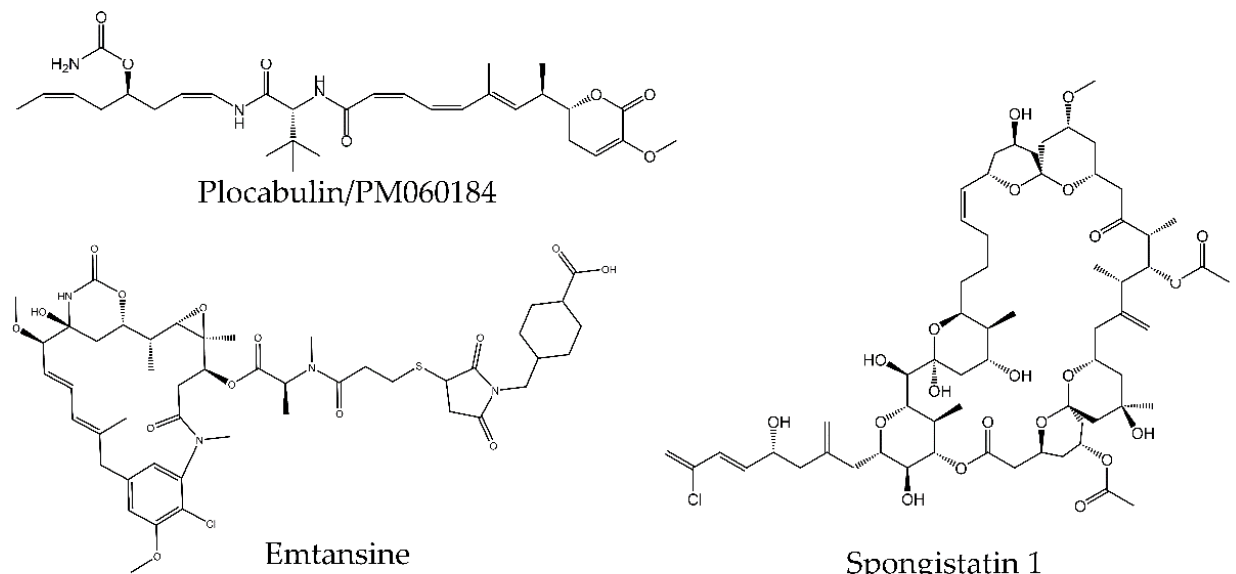

Spongistatin 1

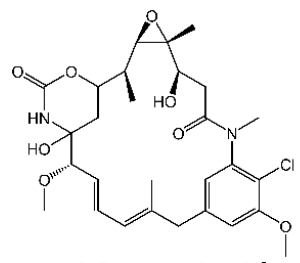

Maytansinoid

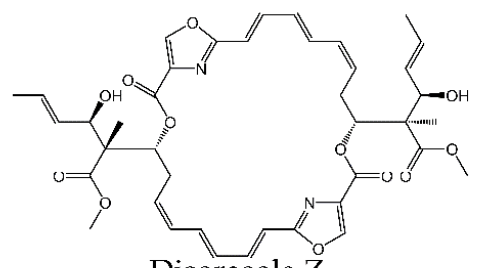

Disorasole Z

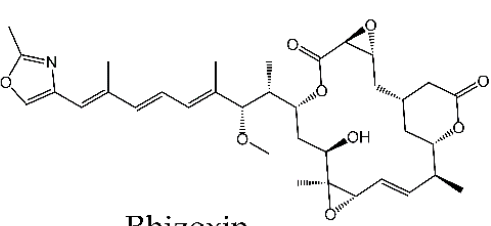

Rhizoxin

Figure 6. Structure of maytansinoid, disorazole Z, emtasine, rhizoxin, PM060184, and spongistatin 1.

The experimental evidence indicates that the inhibitory effect of maytansine-site ligands is a direct consequence of the occupation of the $\beta$-tubulin pocket. In growing microtubules, the maytansine-binding pocket of the MT plus end $\beta$-tubulin accommodates the minus end structures of the $\alpha$-tubulin of a newly added heterodimer, including S8, H8, and loop H10-S9 [171]. Incorporation of maytansine-site ligands prevent this interaction, impeding MT elongation (Figure 2).

\subsubsection{Colchicine Site}

Colchicine (Figure 7) was isolated from autumn crocus Colchicum autumnale. This alkaloid contains three rings, of which rings $\mathrm{A}$ and $\mathrm{C}$ bind to $\beta$-tubulin, while aromatic ring $\mathrm{B}$ binds to $\alpha$-tubulin [172]. Colchicine-tubulin binding is a slow, strongly temperature-dependent, and practically irreversible process [173]. Although colchicine has been used clinically in the treatment of nonneoplastic diseases (gout, familial Mediterranean fever), neither colchicine nor other related compounds were successful as chemotherapeutic agents owing to their severe toxicity to normal tissues at doses required for antitumor effects [174,175]. 


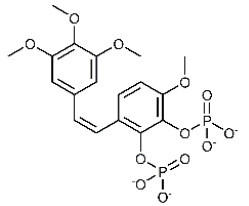

Combrestatin A-1 phosphate/OXi4503

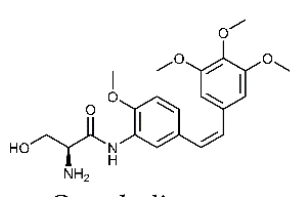

Omrabulin

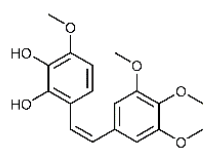

Combrestatin A-1

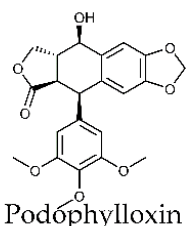

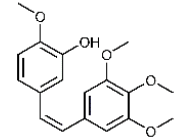

Combrestatin A-4

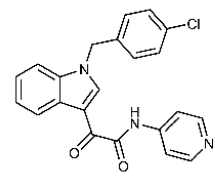

Indibulin

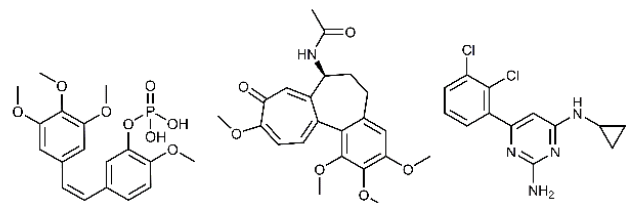

Colchicine

TH588

Figure 7. Structure of colchicine, combretastatin A-1, combretastatin A-4, OXi 4503, fosbretabulin, ombrabulin, 2-methoxyestradiol, chalcone: trans-1-(2,5-dimethoxy)-3-[4 (dimethylamino) phenyl]-2-methyl-2-propen-1-one (MDL 27048), podophyllotoxin, indibulin, and TH588.

Over the last few decades, compounds of low toxicity which target the colchicine site have been reported (Figure 7), including derivatives of stilbenoid-combretastatins (combretastatin A-1 phosphate/OXi4503, combretastatin A-1, combretastatin A-4, fosbretabulin, ombrabulin), chalcones (MDL 27048), compounds with furonaphthodioxole skeleton (podophyllotoxin), derivatives of indole (indibulin), and natural metabolite of estradiol (2-methoxyestradiol). While no colchicine-site MTAs are currently approved for cancer treatment, several are in phase I/III clinical trials [174] (for a review, see [175]).

Recently, a compound initially designed as MTH1 (Mut T homolog 1) inhibitor, TH588, was shown to dock into the colchicine-binding pocket [176]. By reducing microtubule plus end dynamics, this cyclopropyl analog affects tubulin polymerization, resulting in disruption of mitotic spindles, prolongation of mitosis and, eventually, apoptosis [176-178]. Preclinical studies show promising results for the use of TH588 as an anticancer drug $[179,180]$.

The colchicine-binding site is located near the plus end surface of $\beta$-tubulin in the center of the tubulin heterodimer at the interface between $\alpha$ - and $\beta$-tubulin. It is a big pocket formed by the hydrophobic and polar residues of H7, H8, S7, S8, and loop H7-H8 (T7 loop) that can be divided into three zones: central zone 2 and two accessory zones, zone 1 facing $\alpha$-tubulin and zone 3 buried deeper within the $\beta$-tubulin pocket $[181,182]$.

Binding of colchicine-site ligands to heterodimer causes its stabilization in the curved conformation (Figure 2) [181]. As mentioned, during MT polymerization, tubulin dimers at the MT tip undergo a transition from curved to straight conformation, which requires a shift of several $\beta$-tubulin structures (S8-S9 and H8) closer to each other. As a result, the colchicine pocket is contracted [24,181]. While the colchicine pocket is occupied by a ligand, such conformational changes cannot occur, making colchicine ligand-bound heterodimer incompetent for polymerization [24,181].

\subsubsection{Pironetin Site}

Pironetin (Figure 8), a polyketide, is a natural product that was first extracted from fermentation broths of Streptomyces sp. $[183,184]$. It is worth noting that pironetin is, to date, the only known compound that exclusively targets the $\alpha$-tubulin subunit and covalently binds to Cys316 of $\alpha$-tubulin $[185,186]$. The molecule and its derivates are currently under investigation and display promising anticancer properties (reviewed in [187]). 


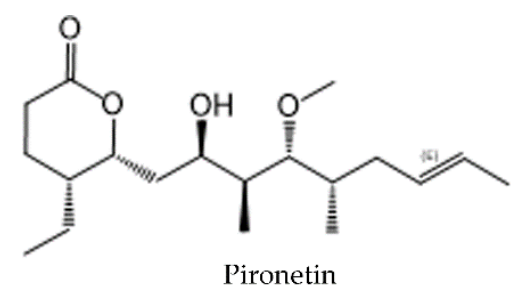

Figure 8. Structure of pironetin.

The pironetin-binding site is the only known pocket on $\alpha$-tubulin targeted by MTAs. Its main part is formed by residues of S8, S10, and H7, but residues of S4, S5, and S6 also participate in the ligand accommodation [185]. The binding of pironetin leads to conformational changes of $\alpha$-tubulin within the minus end, including disordering of loop H7-H8 (T7 loop) and part of H8 [185]. Since these structures are required for the formation of longitudinal interactions within protofilaments, it was proposed that pironetin prevents MT polymerization by the formation of assembly-incompetent pironetin-bound tubulin dimers (Figure 2) [185].

\section{Factors Affecting Microtubule Dynamics in Cancer Cells}

Carcinogenesis is a multistep process involving, among other actions, a remodeling of the cytoskeleton. The transformation from highly polarized epithelial cells to multipolar spindle-like metastatic cells that are able to detach from the extracellular matrix and migrate requires extensive reorganization of the cytoskeleton, including microtubules, during a process called epithelial-mesenchymal transition (EMT) (for a review, see [188]). The abnormalities of mitotic spindle and consequent aberrant cell cycle progression and division lead to genomic instability (for a review, see [189]). Thus, it is not surprising that numerous alterations in tubulins, including mutations and variations in isotype expression level, post-translational modifications, and MAP composition, were identified in cancer cells.

\subsection{Tubulin Isotypes in Cancer and Anticancer Drug Resistance}

Altered expression of tubulin isotypes is considered to be a hallmark in a range of cancers. Analysis of clinical specimens has shown that in many cancers, a high expression of several $\beta$-tubulin isotypes correlates with aggressive clinical behavior, chemotherapy drug resistance, and poor patient outcome [121]. Strikingly, little is known about the level of tubulin isoforms in primary nontreated cancers, while numerous studies indicate their variations after chemotherapy, especially after taxane-based treatment [121]. In fact, some data show that in cancer cell lines, paclitaxel can itself induce the expression of specific tubulin isoforms [190].

An increase in $\beta \mathrm{I}$ expression was observed in several cancers, including breast, colon, and kidney cancer, while its level was decreased in prostate cancer (Table 2) [43,191-193]. In the case of ovarian cancer, the data are inconsistent as both increased and invariant levels of $\beta I$ expression were reported [43,191,194,195]. High $\beta I$ expression is associated with the acquisition of chemoresistance to MTAs and poor prognosis in ovarian serous carcinoma and lung adenocarcinoma, but not in lung squamous cell carcinoma $[191,193,196]$. Interestingly, recent data show that experimentally lowering $\beta I$ level by siRNA or mir-195 microRNA sensitizes adenocarcinoma cell lines to paclitaxel and eribuline [193], indicating a direct correlation between $\beta I$ level and MTA resistance, at least in non-small-cell lung adenocarcinomas.

$\beta$ IIIa and $b$ differ by only two amino acids and, thus, the expression of these two isotypes can be distinguished at the RNA level but not at the protein level. Using PCR, it was shown that $\beta$ IIa is increased in NSCLC, prostate, and ovarian cancers, and decreased in kidney, colon, and breast cancers [43], while $\beta \mathrm{IIb}$ is increased in ovarian cancer and decreased in kidney, colon, and breast cancers [43]. Increased $\beta$ IIlb isoform was also recently associated with the metastatic stage of melanoma, indicating its role in EMT transition [197]. $\beta \mathrm{II}$ was also examined at the protein level in several cancer 
types, including head and neck carcinomas (LASCCHN), ovarian carcinoma, colorectal cancer, and breast cancer cell lines [194,196,198].

Table 2. Tubulin isotypes as survival and MTA-resistance prognostic markers in cancer.

\begin{tabular}{|c|c|c|c|c|}
\hline $\begin{array}{l}\text { High Level of Tubulin } \\
\text { Expression }\end{array}$ & Cancer & Prognosis & Resistance to & Reference \\
\hline$\alpha \mathrm{Ia}$ & renal & poor & $\mathrm{n} / \mathrm{a}$ & [38] \\
\hline$\alpha \mathrm{Ib}$ & $\begin{array}{l}\text { hepatocellular carcinoma } \\
\text { renal, breast }\end{array}$ & poor & $\begin{array}{c}\text { paclitaxel } \\
\mathrm{n} / \mathrm{a}\end{array}$ & $\begin{array}{c}{[199]} \\
{[38]}\end{array}$ \\
\hline$\alpha \mathrm{Ic}$ & $\begin{array}{l}\text { liver, renal, pancreatic, colon, } \\
\text { breast, lung }\end{array}$ & poor & $\mathrm{n} / \mathrm{a}$ & [38] \\
\hline$\alpha \mathrm{IVa}$ & liver & poor & n/a & [38] \\
\hline \multirow[t]{2}{*}{$\beta I$} & $\begin{array}{l}\text { ovarian } \\
\text { breast }\end{array}$ & $\begin{array}{l}\text { not determined } \\
\text { not determined }\end{array}$ & $\begin{array}{l}\text { paclitaxel } \\
\text { docetaxel }\end{array}$ & {$\left[\begin{array}{l}{[191]} \\
{[200]}\end{array}\right.$} \\
\hline & NSCLC adenocarcinomas & Hot aetermuned & $\begin{array}{l}\text { paclitaxel and } \\
\text { eribulin }\end{array}$ & [193] \\
\hline \multirow[t]{2}{*}{$\beta I I$} & breast & not determined & docetaxel & {$[196,201]$} \\
\hline & $\begin{array}{l}\text { lung adenocarcinoma cell } \\
\text { line }\end{array}$ & not determined & paclitaxel & [191] \\
\hline ßIIa & $\begin{array}{c}\text { urothelial } \\
\text { renal }\end{array}$ & $\begin{array}{l}\text { poor } \\
\text { good }\end{array}$ & $\begin{array}{l}\mathrm{n} / \mathrm{a} \\
\mathrm{n} / \mathrm{a}\end{array}$ & {$\left[\begin{array}{l}{[38]} \\
{[38]}\end{array}\right.$} \\
\hline$\beta \mathrm{IIlb}$ & endometrial & poor & $\mathrm{n} / \mathrm{a}$ & [38] \\
\hline \multirow[t]{15}{*}{$\beta \mathrm{III}$} & $\begin{array}{l}\text { prostate } \\
\text { colon }\end{array}$ & $\begin{array}{l}\text { poor } \\
\text { poor }\end{array}$ & $\begin{array}{l}\text { docetaxel } \\
\text { paclitaxel }\end{array}$ & $\begin{array}{c}{[202,203]} \\
{[204]}\end{array}$ \\
\hline & bladder, cisplatin resistant & $\begin{array}{l}\text { poor after paclitaxel } \\
\text { chemotherapy }\end{array}$ & $\mathrm{n} / \mathrm{a}$ & [205] \\
\hline & gastric & poor & $\mathrm{n} / \mathrm{a}$ & [206] \\
\hline & gastric metastatic & $\begin{array}{l}\text { poor after taxane } \\
\text { chemotherapy }\end{array}$ & $\mathrm{n} / \mathrm{a}$ & [207] \\
\hline & uterine serous carcinoma & poor & $\begin{array}{l}\text { paclitaxel, } \\
\text { sensitivity to } \\
\text { epothilone }\end{array}$ & [208] \\
\hline & lung carcinoma cell line & $\mathrm{n} / \mathrm{a}$ & epothilone & [209] \\
\hline & NSCLC & poor & vinorelbine & [210] \\
\hline & NSCLC stage III/IV & $\begin{array}{l}\text { poor } \\
\text { good after }\end{array}$ & vinorelbine & [211] \\
\hline & NSCLC stage I/II & $\begin{array}{c}\text { cisplatin/vinorelbine } \\
\text { adjuvant } \\
\text { chemotherapy }\end{array}$ & $\mathrm{n} / \mathrm{a}$ & [212] \\
\hline & ovarian & poor & $\mathrm{n} / \mathrm{a}$ & [213] \\
\hline & ovarian clear cell carcinoma & $\begin{array}{l}\text { good after taxane } \\
\text { based chemotherapy }\end{array}$ & & {$[214]$} \\
\hline & breast & poor & $\mathrm{n} / \mathrm{a}$ & [215] \\
\hline & breast & not determined & $\begin{array}{l}\text { sensitivity to } \\
\text { taxanes }\end{array}$ & {$[216]^{*}$} \\
\hline & metastatic breast & invariant & $\begin{array}{c}\text { sensitivity to } \\
\text { docetaxel treatment }\end{array}$ & [217] \\
\hline & melanoma & $\begin{array}{c}\text { difference not } \\
\text { statistically significant }\end{array}$ & paclitaxel & [218] \\
\hline$\beta I V a$ & endometrial & poor & $\mathrm{n} / \mathrm{a}$ & [38] \\
\hline \multirow[t]{2}{*}{$\beta \mathrm{IVb}$} & liver & poor & $\mathrm{n} / \mathrm{a}$ & [38] \\
\hline & thyroid, endometrial & good & $\mathrm{n} / \mathrm{a}$ & [38] \\
\hline \multirow[t]{3}{*}{$\beta V$} & $\begin{array}{c}\text { renal, } \\
\text { urothelial }\end{array}$ & poor & $\mathrm{n} / \mathrm{a}$ & [38] \\
\hline & NSCLC & good & $\begin{array}{l}\text { good response to } \\
\text { paclitaxel and } \\
\text { vinorelbine }\end{array}$ & [219] \\
\hline & breast & not determined & $\begin{array}{l}\text { sensitivity to } \\
\text { taxanes }\end{array}$ & {$[216]^{*}$} \\
\hline
\end{tabular}

${ }^{*}$ only mRNA level was determined.

Similar to $\beta I$, in lung adenocarcinoma, breast cancer, and breast cancer cell lines, an increased level of $\beta$ II was associated with resistance to MTA [191,196,201], while in LASCCHN, it was associated with poor survival after chemotherapy [198]. By contrast, in taxane-treated ovarian carcinomas, poor outcome is associated with a low level of $\beta$ II [194]. Interestingly, silencing of $\beta$ II by siRNA in NSCLC adenocarcinoma and large-cell carcinoma cell lines increases cell sensitivity to vinca alkaloids but not to paclitaxel treatment [220]. 
In a number of cancers (mainly of epithelial origin) $\beta$ II was observed within the nucleus of both cancer cells and nontransformed cells in tissues adjacent to the cancer [221]. Nuclear localization of $\beta$ II was recently associated with poor outcomes in colorectal cancer patients [222].

It was surprising when the neural tubulin isoform $\beta I I I$, which increases MT dynamics (see above), was discovered to be expressed in tumors with different origins. An analysis of the significant number of different types of tumors revealed that the contribution of $\beta \mathrm{III}$ to the total tubulin pool depended on the cancer type [223]. For example, in nearly $70-80 \%$ of the examined cases of small-cell lung cancer, mesothelioma, NSCLC, adenocarcinoma and large-cell cancer, neuroendocrine pancreatic cancer, malignant melanoma, and gallbladder carcinoma, $\beta$ III was expressed at high levels [223]. By contrast, 70-95\% of cases of breast cancer, colon adenoma, stomach cancer, basalioma, Warthin's tumor, and hepatocellular carcinoma were $\beta$ III-negative [223].

In a wide range of tumors and cancer cell lines, including small-cell lung carcinoma, NSCLC, ovarian, prostate, bladder, uterine, upper gastrointestinal, colon, pancreatic, LASCCHN, and gastric cancer, $\beta$ III upregulation is associated with the development of resistance to taxane-based chemotherapy and poor clinical outcome [121,200,202-208,210-213,215,223-233]. Moreover, an increased $\beta$ III level was also shown to be associated with EMT and cell motility of colon cancer cell lines [234].

The role of the $\beta$ III isoform in tumorigenesis was confirmed in a pancreatic cell line model. Silencing of $\beta I I I$ expression by shRNA or mir-200c microRNA reduced cancer cell growth and tumorigenic potential both in vitro and in vivo in orthotopic and xenographic pancreatic cancer mouse models $[190,230]$.

A high level of $\beta$ III is generally believed to be a bad prognostic marker for MTA resistance and survival. However, it was recently shown that a paclitaxel-resistant NSCLC adenocarcinoma cell line with increased $\beta$ III expression was sensitive to vinblastine and its analogs to the same extent as "parental" cells with low taxane resistance and lower $\beta I I I$ expression [235]. This indicates that $\beta$ III-induced taxane resistance may not influence resistance to other MTAs. In contrast to these observations, overexpression of $\beta$ III-tubulin in ovarian clear cell adenocarcinoma is a predictor of a good response to taxane-based chemotherapy, and cases with higher $\beta$ III-tubulin expression are associated with a significantly more favorable prognosis than those with lower $\beta$ III-tubulin expression [214]. A similar observation was made for early stages (I/II) of breast cancer [212].

Altered expression of the $\beta I V$ isotype was also reported in numerous cancers, including ovarian, lung, prostate, breast, and kidney cancers and breast and lung cancer cell lines [43,191,194,196,220]; the data, however, are frequently inconsistent. For example, some data indicate decreased $\beta I V$ in lung and breast cancer [43], while studies on cancer cell lines indicate increased $\beta I V$ expression, especially in taxane-resistant cell lines [191,196].

Similar to $\beta \mathrm{II}, \beta \mathrm{IVb}$ overexpression is associated with resistance to vinca alkaloids rather than taxanes. In fact, siRNA knockdown of IVb $\beta$-tubulin expression in NSCLC and pancreatic ductal carcinoma cell lines increases the response to vinca alkaloids $[220,236]$. Interestingly, downregulation of $\beta \mathrm{IVb}$ was recently observed in an EMT-induced colon cancer cell line and transformation of epithelium-like to spindle-like cell morphology in these cells was reversed by $\beta I V b$ overexpression [237].

The level of $\beta V$ expression was tested on RNA and protein levels. The level of $\beta V$ RNA was shown to be reduced in most tumors (colon, ovary, prostate, breast, lung) except for kidney [43], while $\beta \mathrm{V}$ protein level was shown to be elevated in lung, breast, and ovarian cancers and decreased in prostate cancer $[238,239]$. In NSCLC, a low level of $\beta V$-tubulin was associated with poor prognosis after paclitaxel-based chemotherapy [219].

Based on the available data, it appears that different $\beta$-tubulin isotypes play specific roles in the cancer cell response to extrinsic factors influencing MT dynamics. For example, in breast cancer patients with both $\beta I$ and $\beta$ III upregulation, response to taxane-based therapy was poor; in the group with a low level of both, the majority of patients responded well to the therapy, while in groups where one $\beta$-tubulin isotype high and another low, the response was intermediate [200]. Similar, in NSCLC patients with a low level of $\beta \mathrm{V}$ and high level of $\beta \mathrm{III}$ expression, the outcome was much worse than in 
patients with high $\beta V$ and low $\beta$ III, while patients with either a high or low level of both isotypes had an intermediate outcome [219].

Thus, the outcome of levels and ratios of particular $\beta$ tubulin isotypes in terms of the progression of carcinogenesis appears to be specific to tumor type.

MTA resistance in cancer could also be related to mutations of $\beta$-tubulin. However, analyses of the clinical samples revealed that mutations in $\beta$-tubulin are either not present or very rare. Thus, it seems unlikely that mutations in $\beta$-tubulin could play an important role in drug resistance (reviewed in [240]).

Studies conducted on cell lines showed that mutations of predominating $\beta$-tubulin isotypes within the taxane-, colchicine-, and vinca-binding sites can be associated with altered MT dynamics and/or resistance to MTA (reviewed in [240-242]). Most $\beta$-tubulin mutations located within close proximity to the taxane-binding site did not change the affinity of tubulin to taxanes or epothilones, but probably destabilized MTs in the absence of any drugs [242]. Only mutation at F270V, T274I, and R282N residues were reported to have a direct effect on drug-binding affinity [242]. A similar effect was observed when point mutations were located in the M-loop (T274I, R282Q) or in helix H9, which is essential for interdimer interactions (Q292E) [242].

A recent study on a large number of samples of breast cancer tumors identified several mutations in $\beta \mathrm{I}, \beta \mathrm{IIa}$, and $\beta \mathrm{IVb}$ tubulins in which a gene-encoded residue was replaced by the amino acid present in the corresponding position in $\beta$ III [243]. It was proposed that such mutations could influence the clinical outcome in a similar manner as overexpression of $\beta$ III-tubulin [243].

\subsection{Microtubule PTMs and Cancer}

Changes in the level of tubulin modifications were linked to tumorigenesis (Table 3) $[29,244]$. Downregulation of TTL and increased $\alpha$-tubulin detyrosination were reported during the epithelial-mesenchymal transition (EMT) that occurs during tumor invasion [245] in prostate cancer cells [246], in aggressive subtypes of breast cancer cells [247], and in primary neuroblastomas with poor prognosis [248]. The recent discovery of the vasohibin (VASH)/small vasohibin-binding protein (SVBP) complex, reported as a detyrosinating enzyme, tubulin carboxypeptidase (TCP) [249,250], provides new links between this tubulin modification and already known associations between vasohibin dysfunction and cancer [251,252].

A high $\Delta 2 \alpha$-tubulin level in non-small-cell lung cancer (NSCLC) cells was associated with shorter overall patient survival and resistance to vinorelbine [211]. On the contrary, $\Delta 2 \alpha$-tubulin was undetectable in prostate cancer cell lines (LNCaP and PC3), but was present in control cells [246].

Tubulin acetylation is associated with several types of cancer. An increased level of acetylation was reported in head and neck squamous cell carcinoma, for which it can be used as a prognostic marker [253]. An elevated level of tubulin acetylation in breast cancer cell line (MCF-7) is associated with the development of colchicine-resistance [254]. Additionally, a higher level of acethylated tubulin in primary breast tumors is linked to the basal-like subtype of breast cancer, in which it promotes adhesion and invasion of breast cancer cells, increasing the risk of disease progression and death [255]. Overexpression of ATAT1 in cultured nonmetastatic lines of breast cancer cells promoted the formation of microtubule-based membrane protrusions, structures characteristic of metastasis [255]. The level of microtubule acetylation was also shown to affect epithelial-mesenchymal transition and cell polarity [256].

Recent studies provide evidence that phosphorylation of serine 21 of HDAC6 by G protein-coupled receptor kinase 5 (GRK5) promotes deacetylase activity in ovarian (HeLa) and breast (MDA MB 231) cancer cell lines. An increased level of acetylated $\alpha$-tubulin sensitizes these cells to the anti-apoptotic activity of paclitaxel [257]. The high expression of HDAC6 was also linked to poor prognosis of oral squamous cell carcinoma (OSCC) [258], oncogenic transformation [259], and EMT [260]. 
Table 3. Alterations in tubulin post-translational modifications (PTMs) in cancer.

\begin{tabular}{|c|c|c|c|c|}
\hline PMT & Changes & Cancer & Outcome & Reference \\
\hline 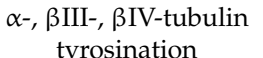 & elevated level & breast cancer cell lines & paclitaxel resistance & [261] \\
\hline \multirow[t]{3}{*}{$\begin{array}{c}\alpha \text {-tubulin } \\
\text { detyrosination }\end{array}$} & $\begin{array}{l}T T L \text { down } \\
\text { regulation }\end{array}$ & breast cancer lines, & $\begin{array}{l}\text { increasing metastasis and } \\
\text { tumor aggressiveness }\end{array}$ & [245] \\
\hline & & $\begin{array}{l}\text { non-epithelial tumor of } \\
\text { different origin }\end{array}$ & $\begin{array}{l}\text { tumor growth correlates } \\
\text { with loss of TTL activity } \\
\text { impaired neuronal }\end{array}$ & [262] \\
\hline & & primary neuroblastomas & $\begin{array}{l}\text { differentiation and poor } \\
\text { prognosis }\end{array}$ & [248] \\
\hline \multirow[t]{3}{*}{$\Delta 2 \alpha$-tubulin } & elevated level & prostate cancer cell lines & $\mathrm{n} / \mathrm{a}$ & [246] \\
\hline & & $\begin{array}{c}\text { non-small-cell lung } \\
\text { cancer }\end{array}$ & $\begin{array}{c}\text { poor outcome, } \\
\text { vinorelbine resistance }\end{array}$ & [211] \\
\hline & & breast cancers & $\begin{array}{l}\text { high aggressiveness and } \\
\text { poor prognosis }\end{array}$ & [247] \\
\hline$\Delta 2 \beta \mathrm{IVb}$-tubulin & & hepatic carcinoma (rat) & $\begin{array}{l}\text { increased in cancer with } \\
\text { respect to healthy liver }\end{array}$ & [263] \\
\hline \multirow[t]{10}{*}{$\alpha$-tubulin acetylation } & $\begin{array}{c}\text { HDAC6 } \\
\text { knockdown }\end{array}$ & $\begin{array}{c}\text { ovarian, breast } \\
\text { epidermoid carcinoma } \\
\text { cell lines }\end{array}$ & mitotic arrest, and cell death & [259] \\
\hline & HDAC6 inhibition & nsclc cell lines & marker of better prognosis & [264] \\
\hline & $\begin{array}{c}\text { HDAC6 } \\
\text { overexpression }\end{array}$ & breast cancer & good prognosis & [265] \\
\hline & & $\begin{array}{l}\text { oral squamous cell } \\
\text { carcinoma }\end{array}$ & correlates with tumor stage & [258] \\
\hline & $\begin{array}{c}\text { MEC-17 } \\
\text { overexpression }\end{array}$ & $\begin{array}{l}\text { lung cancer animal } \\
\text { model }\end{array}$ & $\begin{array}{l}\text { cancer cells migration and } \\
\text { facilitated invasiveness }\end{array}$ & [256] \\
\hline & $\begin{array}{c}\text { MEC-17 } \\
\text { downregulation }\end{array}$ & & higher tumor grade & [256] \\
\hline & $\begin{array}{l}\text { elevated level of } \\
\text { tubulin acetylation }\end{array}$ & head and neck cancer & correlates with tumor grade & [253] \\
\hline & & primary breast tumors & $\begin{array}{l}\text { correlates with metastatic } \\
\text { phenotype }\end{array}$ & [255] \\
\hline & & breast cancer cell lines & colchicine-resistance & [254] \\
\hline & & $\begin{array}{l}\text { ovarian and breast } \\
\text { cancer cell lines }\end{array}$ & paclitaxel sensitivity & [257] \\
\hline \multirow[t]{2}{*}{ Glutamylation } & elevated levels & prostate cancer cells & $\mathrm{n} / \mathrm{a}$ & [246] \\
\hline & & breast cancer cell lines & colchicine-resistance & [254] \\
\hline Glycylation & $\begin{array}{c}\text { TTLL3 } \\
\text { downregulation }\end{array}$ & colorectal cancer & $\begin{array}{c}\text { risk factor for carcinoma } \\
\text { development }\end{array}$ & [266] \\
\hline $\begin{array}{l}\text { Phosphorylation of } \\
\alpha \text {-tubulin (Ser 165) }\end{array}$ & $\begin{array}{l}\text { dephosphorylated } \\
\text { (S165D) } \alpha \text {-tubulin }\end{array}$ & breast cancer cell lines & $\begin{array}{l}\text { hyperproliferation and } \\
\text { increased metastatic } \\
\text { potential }\end{array}$ & [267] \\
\hline
\end{tabular}

Phosphorylation of $\alpha$-tubulin at Ser 165 residue by protein kinase $C$, in turn, stimulates microtubule dynamics in human breast cancer cells $[78,79,267]$. It seems that phosphorylation of $\alpha$-tubulin at Ser 165 can act as a switch that controls the expression of EMT markers in nontransformed human breast cells and the rate of proliferation of breast tumors $[79,267]$.

A few studies suggested that changes in the levels of tubulin glutamylation [246] and glycylation [266] are observed during tumorigenesis. Some unusual post-translational modifications have been detected in lung and hepatic cancers. The removal of the final two residues of the $\beta$ IVb-tubulin C-terminal tail was identified in more advanced stages of liver cancer and metastasis to lung in a rat model of hepatic carcinoma [263].

\subsection{Microtubule-Associated Proteins and Cancer}

The data concerning MAPs in cancer are limited. Up to now, only a few MAPs, including Stathmin-1, EB1, CLIP-170/CLIP1, and some structural MAPs, have been associated with cancerogenesis, outcome prognosis, and chemotherapy sensitivity [268-271].

As already mentioned, Stathmin-1 was originally identified as an oncoprotein. Elevated levels of Stathmin-1 is a poor prognostic factor in many cancers, including leukemia, prostate, breast, lung, ovarian, cervical, endometrial, oral nasopharyngeal gastric, and colorectal cancers [272-280]. 
Some studies suggested that the silencing of the Stathmin-1-encoding gene can inhibit cancer cell migration and metastatic potential [281]. The data concerning correlation of the level of Stathmin-1 expression and resistance of cancer to chemotherapy are contradictory. Several studies show that Stathmin-1 overexpression increases the sensitivity of breast and lung cancer cells to taxanes and/or vinca alkaloids [282,283]. However, in epithelial carcinomas, nasopharyngeal carcinomas, breast cancer, and esophageal squamous cell cancer, the increased taxane sensitivity was correlated with Stathmin-1 silencing [284-288]. Interestingly, not only the protein level but also its phosphorylation state was correlated with cancerogenesis and drug resistance [289].

Increased levels of EB1 and CLIP-170/CLIP1, two + TIP proteins, enhances paclitaxel sensitivity in breast cancer cell lines and the response to taxane-containing therapy in patients [290,291]. On the other hand, a decrease of CLIP-170/CLIP1 expression correlates with patients survival in the case of glioma [292].

Structural MAPs have also been related with carcinogenesis. The expression of neuronal MAPs, Tau, MAP2, and MAP4 was detected in non-neuronal cancer tissues. For example, Tau overexpression observed in breast and ovarian cancer cells was correlated with a poor outcome [293-295], while downregulation of Tau in breast and ovarian cancer cell lines increased sensitivity to paclitaxel [293,295]. Because Tau and taxanes bind to the same tubulin surface, it was proposed that Tau may compete with paclitaxel for binding to $\beta$-tubulin, causing taxane ineffectiveness $[293,295]$. On the other hand, in mice, docetaxel-sensitive pancreatic neoplasms show a higher level of Tau and MAP2 with respect to those that are docetaxel-resistant [296,297].

MAP2 was proposed as a diagnostic marker in pulmonary neuroendocrine carcinomas, some non-small-cell lung carcinomas [298], Merkel cell carcinomas [299], and oral squamous cell carcinoma [300], but not in metastatic melanomas (while abundant in primary melanomas) [301]. Overexpression of MAP2 in melanoma cell lines leads to microtubule stabilization, associated with G2-M phase cell cycle arrest, growth inhibition, and cancer cell apoptosis, both in vitro and in a nude mouse model [301,302]. Decrease of MAP2c accompanied with a decrease in $\beta$ III-tubulin expression was also observed in vinca-resistant neuroblastoma cell lines [303].

Recently, also, MAP1B was shown to be expressed and a marker of a poor outcome in urothelial cancer [270]. Silencing of MAP1B in urothelial cancer cell lines decreased the cell migration and invasiveness [270].

An elevated level of MAP4 and resistance to vinca alkaloids have been observed in childhood acute lymphoblastic leukemia (ALL) cells [304], while leukemia cell lines resistant to the epothilone and hypersensitive to microtubule-destabilizing agents increased the levels of both MAP4 and $\beta$ III tubulin [305]. In esophageal squamous cell carcinoma, an increased level of MAP4 was shown to be a poor outcome marker, and its intratumor silencing inhibited cell growth in nude mice [306]. Very similar observations were also made in lung adenocarcinoma [307].

An increased level of MAP7 is a marker of poor prognosis in leukemia and cervical cancers [269,308,309]. Moreover, it was shown that MAP7 promotes migration and invasiveness of cervical cancer cell lines by inducing EMT transition [309].

\section{Conclusions and Perspectives}

Microtubule dynamics play a key role in the proper execution of cell division. Thus, it is not surprising that a large number of MTAs have found application as clinical drugs against different types of cancers. Unfortunately, MTAs are also toxic to healthy tissues. Therefore, reducing the toxicity of anticancer MTAs and understanding the causes of cancer cell resistance are extremely important. The main direction of research worldwide includes: (i) a comprehensive understanding of the tubulin code in cancer cells and the selective manipulation of tubulin isotype expression [121], (ii) an improvement of the potency of drugs and increased tumor specificity [18], (iii) combination therapy, with nanoparticles and anticancer drugs working synergistically to delay the onset of drug 
resistance [310], and (iv) the use of antibody-drug conjugates (ADCs) as a potent class of anticancer therapeutics that confer selective and sustained cytotoxic drug delivery to tumor cells.

Author Contributions: All authors searched and organized data concerning selected chapter. H.F. and E.J. prepared initial version of the manuscript, F.B. and E.J. also prepared figures. All authors worked on the final version of the manuscript. All authors have read and agreed to the published version of the manuscript.

Acknowledgments: We thank Dorota Wloga for a critical reading of the manuscript. This work implemented as a part of Operational Project Knowledge Education Development 2014-2020 co-financed by European Social Fund, and was also supported from National Science Centre, Poland, Opus15, 2018/29/B/NZ3/02443 to E.J. and statutory funds from the Nencki Institute of Experimental Biology of the Polish Academy of Sciences.

Conflicts of Interest: The authors declare no conflict of interest.

\section{References}

1. Roostalu, J.; Surrey, T. Microtubule Nucleation: Beyond the Template. Nat. Rev. Mol. Cell Biol. 2017, 18, 702-710. [CrossRef] [PubMed]

2. Akhmanova, A.; Steinmetz, M.O. Control of Microtubule Organization and Dynamics: Two Ends in the Limelight. Nat. Rev. Mol. Cell Biol. 2015, 16, 711-726. [CrossRef]

3. Muroyama, A.; Lechler, T. Microtubule Organization, Dynamics and Functions in Differentiated Cells. Development 2017, 144, 3012-3021. [CrossRef] [PubMed]

4. Carvalho-Santos, Z.; Azimzadeh, J.; Pereira-Leal, J.B.; Bettencourt-Dias, M. Tracing the Origins of Centrioles, Cilia, and Flagella. J. Cell Biol. 2011, 194, 165-175. [CrossRef] [PubMed]

5. Shi, X.; Sun, X. Regulation of Paclitaxel Activity by Microtubule-Associated Proteins in Cancer Chemotherapy. Cancer Chemother. Pharmacol. 2017, 80, 909-917. [CrossRef] [PubMed]

6. Sullivan, K.F. Structure and Utilization of Tubulin Isotypes. Annu. Rev. Cell Biol. 1988, 4, 687-716. [CrossRef]

7. Ludueña, R.F. Multiple Forms of Tubulin: Different Gene Products and Covalent Modifications. Int. Rev. Cytol. 1997, 178, 207-275. [CrossRef]

8. Lu, Q.; Luduena, R.F. In Vitro Analysis of Microtubule Assembly of Isotypically Pure Tubulin Dimers. Intrinsic Differences in the Assembly Properties of Alpha Beta II, Alpha Beta III, and Alpha Beta IV Tubulin Dimers in the Absence of Microtubule-Associated Proteins. J. Biol. Chem. 1994, 269, 2041-2047.

9. Panda, D.; Miller, H.P.; Banerjee, A.; Ludueña, R.F.; Wilson, L. Microtubule Dynamics in Vitro Are Regulated by the Tubulin Isotype Composition. Proc. Natl. Acad. Sci. USA 1994, 91, 11358-11362. [CrossRef]

10. Newton, C.N.; Deluca, J.G.; Himes, R.H.; Miller, H.P.; Jordan, M.A.; Wilson, L. Intrinsically Slow Dynamic Instability of HeLa Cell Microtubules in Vitro. J. Biol. Chem. 2002, 277, 42456-42462. [CrossRef]

11. Verhey, K.J.; Gaertig, J. The Tubulin Code. Cell Cycle 2007, 6, 2152-2160. [CrossRef] [PubMed]

12. Wloga, D.; Joachimiak, E.; Fabczak, H. Tubulin Post-Translational Modifications and Microtubule Dynamics. Int. J. Mol. Sci. 2017, 18, 2207. [CrossRef] [PubMed]

13. Kavallaris, M.; Don, S.; Verrills, N.M. Microtubule-Associated Proteins. In The Role of Microtubules in Cell Biology, Neurobiology, and Oncology; Humana Press: New York, NY, USA, 2009; pp. 83-104. [CrossRef]

14. Kadavath, H.; Hofele, R.V.; Biernat, J.; Kumar, S.; Tepper, K.; Urlaub, H.; Mandelkow, E.; Zweckstetter, M. Tau Stabilizes Microtubules by Binding at the Interface between Tubulin Heterodimers. Proc. Natl. Acad. Sci. USA 2015, 112, 7501-7506. [CrossRef] [PubMed]

15. Jordan, M.A.; Wilson, L. Microtubules as a Target for Anticancer Drugs. Nat. Rev. Cancer 2004, 4, $253-265$. [CrossRef]

16. Dumontet, C.; Jordan, M.A. Microtubule-Binding Agents: A Dynamic Field of Cancer Therapeutics. Nat. Rev. Drug Disc. 2010, 9, 790-803. [CrossRef]

17. Cao, Y.N.; Zheng, L.L.; Wang, D.; Liang, X.X.; Gao, F.; Zhou, X.L. Recent Advances in Microtubule-Stabilizing Agents. Eur. J. Med. Chem. 2018, 143, 806-828. [CrossRef]

18. Steinmetz, M.O.; Prota, A.E. Microtubule-Targeting Agents: Strategies To Hijack the Cytoskeleton. Trends Cell Biol. 2018, 28, 776-792. [CrossRef]

19. Nogales, E.; Wolf, S.G.; Downing, K.H. Structure of the A $\beta$ Tubulin Dimer by Electron Crystallography. Nature 1998, 391, 199-203. [CrossRef]

20. Löwe, J.; Li, H.; Downing, K.H.; Nogales, E. Refined Structure of A $\beta$-Tubulin at 3.5 A Resolution. J. Mol. Biol. 2001, 313, 1045-1057. [CrossRef] 
21. Inclán, Y.F.; Nogales, E. Structural Models for the Self-Assembly and Microtubule Interactions of $\gamma-, \delta$ - and $\varepsilon$-Tubulin. J. Cell Sci. 2001, 114, 413-422.

22. Keays, D.A.; Tian, G.; Poirier, K.; Huang, G.J.; Siebold, C.; Cleak, J.; Oliver, P.L.; Fray, M.; Harvey, R.J.; Molnár, Z.; et al. Mutations in $\alpha$-Tubulin Cause Abnormal Neuronal Migration in Mice and Lissencephaly in Humans. Cell 2007, 128, 45-57. [CrossRef] [PubMed]

23. Brouhard, G.J.; Rice, L.M. Microtubule Dynamics: An Interplay of Biochemistry and Mechanics. Nat. Rev. Mol. Cell Biol. 2018, 19, 451-463. [CrossRef] [PubMed]

24. Dorléans, A.; Gigant, B.; Ravelli, R.B.G.; Mailliet, P.; Mikol, V.; Knossow, M. Variations in the Colchicine-Binding Domain Provide Insight into the Structural Switch of Tubulin. Proc. Natl. Acad. Sci. USA 2009, 106, 13775-13779. [CrossRef] [PubMed]

25. Alushin, G.M.; Lander, G.C.; Kellogg, E.H.; Zhang, R.; Baker, D.; Nogales, E. High-Resolution Microtubule Structures Reveal the Structural Transitions in A $\beta$-Tubulin upon GTP Hydrolysis. Cell 2014, 157, 1117-1129. [CrossRef] [PubMed]

26. Geyer, E.A.; Burns, A.; Lalonde, B.A.; Ye, X.; Piedra, F.A.; Huffaker, T.C.; Rice, L.M. A Mutation Uncouples the Tubulin Conformational and GTPase Cycles, Revealing Allosteric Control of Microtubule Dynamics. Elife 2015, 4, e10113. [CrossRef] [PubMed]

27. Ti, S.C.; Pamula, M.C.; Howes, S.C.; Duellberg, C.; Cade, N.I.; Kleiner, R.E.; Forth, S.; Surrey, T.; Nogales, E.; Kapoor, T.M. Mutations in Human Tubulin Proximal to the Kinesin-Binding Site Alter Dynamic Instability at Microtubule Plus- and Minus-Ends. Dev. Cell 2016, 37, 72-84. [CrossRef]

28. Parker, A.L.; Teo, W.S.; Pandzic, E.; Vicente, J.J.; McCarroll, J.A.; Wordeman, L.; Kavallaris, M. $\beta$-Tubulin Carboxy-Terminal Tails Exhibit Isotype-Specific Effects on Microtubule Dynamics in Human Gene-Edited Cells. Life Sci. Alliance 2018, 1, 1-16. [CrossRef]

29. Prassanawar, S.S.; Panda, D. Tubulin Heterogeneity Regulates Functions and Dynamics of Microtubules and Plays a Role in the Development of Drug Resistance in Cancer. Biochem. J. 2019, 476, 1359-1376. [CrossRef]

30. Ludueña, R.F. Are Tubulin Isotypes Functionally Significant. Mol. Biol. Cell 1993, 4, 445-457. [CrossRef]

31. Verdier-Pinard, P.; Pasquier, E.; Xiao, H.; Burd, B.; Villard, C.; Lafitte, D.; Miller, L.M.; Angeletti, R.H.; Horwitz, S.B.; Braguer, D. Tubulin Proteomics: Towards Breaking the Code. Anal. Biochem. 2009, 384, 197-206. [CrossRef]

32. Tubulins | HUGO Gene Nomenclature Committee. Available online: https://www.genenames.org/data/ genegroup/\#!/group/778 (accessed on 30 July 2020).

33. Gadadhar, S.; Bodakuntla, S.; Natarajan, K.; Janke, C. The Tubulin Code at a Glance. J. Cell Sci. 2017, 130, 1347-1353. [CrossRef] [PubMed]

34. Petrukhin, K.E.; Speer, M.C.; Cayanis, E.; Bonaldo, M.F.; Tantravahi, U.; Soares, M.B.; Fischer, S.G.; Warburton, D.; Gilliam, T.C.; Ott, J. A Microsatellite Genetic Linkage Map of Human Chromosome 13. Genomics 1993, 15, 76-85. [CrossRef] [PubMed]

35. Stanchi, F.; Corso, V.; Scannapieco, P.; Ievolella, C.; Negrisolo, E.; Tiso, N.; Lanfranchi, G.; Valle, G. TUBA8: A New Tissue-Specific Isoform of Alpha-Tubulin That Is Highly Conserved in Human and Mouse. Biochem. Biophys. Res. Commun. 2000, 270, 1111-1118. [CrossRef]

36. Braun, A.; Breuss, M.; Salzer, M.C.; Flint, J.; Cowan, N.J.; Keays, D.A. Tuba8 Is Expressed at Low Levels in the Developing Mouse and Human Brain. Am. J. Hum. Genet. 2010, 86, 819-822. [CrossRef] [PubMed]

37. Poirier, K.; Keays, D.A.; Francis, F.; Saillour, Y.; Bahi, N.; Manouvrier, S.; Fallet-Bianco, C.; Pasquier, L.; Toutain, A.; Tuy, F.P.D.; et al. Large Spectrum of Lissencephaly and Pachygyria Phenotypes Resulting from de Novo Missense Mutations in Tubulin Alpha 1A (TUBA1A). Hum. Mutat. 2007, 28, 1055-1064. [CrossRef] [PubMed]

38. Uhlen, M.; Fagerberg, L.; Hallstrom, B.M.; Lindskog, C.; Oksvold, P.; Mardinoglu, A.; Sivertsson, A.; Kampf, C.; Sjostedt, E.; Asplund, A.; et al. Tissue-Based Map of the Human Proteome. Science 2015, 347, 1260419. [CrossRef]

39. Thul, P.J.; Åkesson, L.; Wiking, M.; Mahdessian, D.; Geladaki, A.; Ait Blal, H.; Alm, T.; Asplund, A.; Björk, L.; Breckels, L.M.; et al. A Subcellular Map of the Human Proteome. Science 2017, 356, eaal3321. [CrossRef]

40. Belvindrah, R.; Natarajan, K.; Shabajee, P.; Bruel-Jungerman, E.; Bernard, J.; Goutierre, M.; Moutkine, I.; Jaglin, X.H.; Savariradjane, M.; Irinopoulou, T.; et al. Mutation of the $\alpha$-Tubulin Tuba1a Leads to Straighter Microtubules and Perturbs Neuronal Migration. J. Cell Biol. 2017, 216, 2443-2461. [CrossRef] 
41. Strassel, C.; Magiera, M.M.; Dupuis, A.; Batzenschlager, M.; Hovasse, A.; Pleines, I.; Guéguen, P.; Eckly, A.; Moog, S.; Mallo, L.; et al. An Essential Role for A4A-Tubulin in Platelet Biogenesis. Life Sci. Alliance 2019, 2, 1-13. [CrossRef]

42. Diggle, C.P.; Martinez-Garay, I.; Molnar, Z.; Brinkworth, M.H.; White, E.; Fowler, E.; Hughes, R.; Hayward, B.E.; Carr, I.M.; Watson, C.M.; et al. A tubulin Alpha 8 Mouse Knockout Model Indicates a Likely Role in Spermatogenesis but Not in Brain Development. PLoS ONE 2017, 12, e0174264. [CrossRef]

43. Leandro-García, L.J.; Leskelä, S.; Landa, I.; Montero-Conde, C.; López-Jiménez, E.; Letón, R.; Cascón, A.; Robledo, M.; Rodríguez-Antona, C. Tumoral and Tissue-Specific Expression of the Major Human $\beta$-Tubulin Isotypes. Cytoskeleton 2010, 67, 214-223. [CrossRef] [PubMed]

44. Guo, J.; Walss-Bass, C.; Ludueña, R.F. The Beta Isotypes of Tubulin in Neuronal Differentiation. Cytoskeleton 2010, 67, 431-441. [CrossRef] [PubMed]

45. Feng, R.; Yan, Z.; Li, B.; Yu, M.; Sang, Q.; Tian, G.; Xu, Y.; Chen, B.; Qu, R.; Sun, Z.; et al. Mutations in TUBB8 Cause a Multiplicity of Phenotypes in Human Oocytes and Early Embryos. J. Med. Genet. 2016, 53, 662-671. [CrossRef] [PubMed]

46. Arai, K.; Shibutani, M.; Matsuda, H. Distribution of the Class II $\beta$-Tubulin in Developmental and Adult Rat Tissues. Cell Motil. Cytoskelet. 2002, 52, 174-182. [CrossRef] [PubMed]

47. Dozier, J.H.; Hiser, L.; Davis, J.A.; Thomas, N.S.; Tucci, M.A.; Benghuzzi, H.A.; Frankfurter, A.; Correia, J.J.; Lobert, S. Beta Class II Tubulin Predominates in Normal and Tumor Breast Tissues. Breast Cancer Res. 2003, 5, R157-R169. [CrossRef]

48. Latremoliere, A.; Cheng, L.; DeLisle, M.; Wu, C.; Chew, S.; Hutchinson, E.B.; Sheridan, A.; Alexandre, C.; Latremoliere, F.; Sheu, S.H.; et al. Neuronal-Specific TUBB3 Is Not Required for Normal Neuronal Function but Is Essential for Timely Axon Regeneration. Cell Rep. 2018, 24, 1865-1879. [CrossRef]

49. Curiel, J.; Bey, G.R.; Takanohashi, A.; Bugiani, M.; Fu, X.; Wolf, N.I.; Nmezi, B.; Schiffmann, R.; Bugaighis, M.; Pierson, T.; et al. TUBB4A Mutations Result in Specific Neuronal and Oligodendrocytic Defects That Closely Match Clinically Distinct Phenotypes. Hum. Mol. Genet. 2017, 26, 4506-4518. [CrossRef]

50. Burley, K.; Westbury, S.K.; Mumford, A.D. TUBB1 Variants and Human Platelet Traits. Platelets 2018, 29, 209-211. [CrossRef]

51. TUBA1A tubulin alpha 1a [Homo sapiens (human)]—Gene-NCBI. Available online: https://www.ncbi.nlm. nih.gov/gene/7846 (accessed on 2 August 2020).

52. TUBA1B tubulin alpha $1 \mathrm{~b}$ [Homo sapiens (human)]—Gene-NCBI. Available online: https://www.ncbi.nlm. nih.gov/gene/10376 (accessed on 30 July 2020).

53. TUBA1C tubulin alpha 1c [Homo sapiens (human)]-Gene-NCBI. Available online: https://www.ncbi.nlm. nih.gov/gene/84790 (accessed on 2 August 2020).

54. TUBA3C tubulin alpha 3c [Homo sapiens (human)]-Gene-NCBI. Available online: https://www.ncbi.nlm. nih.gov/gene/7278 (accessed on 2 August 2020).

55. TUBA3E tubulin alpha 3e [Homo sapiens (human)]—Gene-NCBI. Available online: https://www.ncbi.nlm. nih.gov/gene/112714 (accessed on 2 August 2020).

56. TUBA4A tubulin alpha 4a [Homo sapiens (human)]—Gene-NCBI. Available online: https://www.ncbi.nlm. nih.gov/gene/7277 (accessed on 2 August 2020).

57. TUBA8 tubulin alpha 8 [Homo sapiens (human)]-Gene-NCBI. Available online: https://www.ncbi.nlm. nih.gov/gene/51807 (accessed on 2 August 2020).

58. TUBB tubulin beta class I [Homo sapiens (human)]—Gene-NCBI. Available online: https://www.ncbi.nlm. nih.gov/gene/203068 (accessed on 2 August 2020).

59. TUBB2A tubulin beta 2A class IIa [Homo sapiens (human)]-Gene-NCBI. Available online: https://www. ncbi.nlm.nih.gov/gene/7280 (accessed on 2 August 2020).

60. TUBB2B tubulin beta 2B class IIb [Homo sapiens (human)]-Gene-NCBI. Available online: https://www. ncbi.nlm.nih.gov/gene/347733 (accessed on 2 August 2020).

61. TUBB3 tubulin beta 3 class III [Homo sapiens (human)]-Gene-NCBI. Available online: https://www.ncbi. nlm.nih.gov/gene/10381 (accessed on 2 August 2020).

62. TUBB4A tubulin beta 4A class IVa [Homo sapiens (human)]-Gene-NCBI. Available online: https: //www.ncbi.nlm.nih.gov/gene/10382 (accessed on 2 August 2020).

63. TUBB4B tubulin beta 4B class IVb [Homo sapiens (human)]—Gene-NCBI. Available online: https://www. ncbi.nlm.nih.gov/gene/10383 (accessed on 2 August 2020). 
64. Randazzo, D.; Khalique, U.; Belanto, J.J.; Kenea, A.; Talsness, D.M.; Olthoff, J.T.; Tran, M.D.; Zaal, K.J.; Pak, K.; Pinal-Fernandez, I.; et al. Persistent Upregulation of the $\beta$-Tubulin Tubb6, Linked to Muscle Regeneration, Is a Source of Microtubule Disorganization in Dystrophic Muscle. Hum. Mol. Genet. 2018, 28, 1117-1135. [CrossRef]

65. TUBB6 tubulin beta 6 class V [Homo sapiens (human)]-Gene-NCBI. Available online: https://www.ncbi. nlm.nih.gov/gene/84617 (accessed on 2 August 2020).

66. TUBB1 tubulin beta 1 class VI [Homo sapiens (human)]-Gene-NCBI. Available online: https://www.ncbi. nlm.nih.gov/gene/81027 (accessed on 2 August 2020).

67. TUBB8 tubulin beta 8 class VIII [Homo sapiens (human)]-Gene-NCBI. Available online: https://www.ncbi. nlm.nih.gov/gene/347688 (accessed on 2 August 2020).

68. Ti, S.C.; Alushin, G.M.; Kapoor, T.M. Human $\beta$-Tubulin Isotypes Can Regulate Microtubule Protofilament Number and Stability. Dev. Cell 2018, 47, 175-190. [CrossRef]

69. Ludueña, R.F.; Zimmermann, H.P.; Little, M. Identification of the Phosphorylated $\beta$-Tubulin Isotype in Differentiated Neuroblastoma Cells. FEBS Lett. 1988, 230, 142-146. [CrossRef]

70. Díaz-Nido, J.; Serrano, L.; López-Otín, C.; Vandekerckhove, J.; Avila, J. Phosphorylation of a Neuronal-Specific Beta-Tubulin Isotype. J. Biol. Chem. 1990, 265, 13949-13954. [PubMed]

71. Pamula, M.C.; Ti, S.C.; Kapoor, T.M. The Structured Core of Human $\beta$ Tubulin Confers Isotype-Specific Polymerization Properties. J. Cell Biol. 2016, 213, 425-433. [CrossRef] [PubMed]

72. Vemu, A.; Atherton, J.; Spector, J.O.; Moores, C.A.; Roll-Mecak, A. Tubulin Isoform Composition Tunes Microtubule Dynamics. Mol. Biol. Cell 2017, 28, 3564-3572. [CrossRef]

73. Janke, C.; Magiera, M.M. The Tubulin Code and Its Role in Controlling Microtubule Properties and Functions. Nat. Rev. Mol. Cell Biol. 2020, 21, 307-326. [CrossRef]

74. Roll-Mecak, A. How Cells Exploit Tubulin Diversity to Build Functional Cellular Microtubule Mosaics. Curr. Opin. Cell Biol. 2019, 56, 102-108. [CrossRef]

75. Chu, C.-W.; Hou, F.; Zhang, J.; Phu, L.; Loktev, A.V.; Kirkpatrick, D.S.; Jackson, P.K.; Zhao, Y.; Zou, H. A Novel Acetylation of $\beta$-Tubulin by San Modulates Microtubule Polymerization via down-Regulating Tubulin Incorporation. Mol. Biol. Cell 2011, 22, 448-456. [CrossRef]

76. Ori-McKenney, K.M.; McKenney, R.J.; Huang, H.H.; Li, T.; Meltzer, S.; Jan, L.Y.; Vale, R.D.; Wiita, A.P.; Jan, Y.N. Phosphorylation of $\beta$-Tubulin by the Down Syndrome Kinase, Minibrain/DYRK1a, Regulates Microtubule Dynamics and Dendrite Morphogenesis. Neuron 2016, 90, 551-563. [CrossRef]

77. Fourest-Lieuvin, A.; Peris, L.; Gache, V.; Garcia-Saez, I.; Juillan-Binard, C.; Lantez, V.; Job, D. Microtubule Regulation in Mitosis: Tubulin Phosphorylation by the Cyclin-Dependent Kinase Cdk1. Mol. Biol. Cell 2006, 17, 1041-1050. [CrossRef]

78. Abeyweera, T.P.; Chen, X.; Rotenberg, S.A. Phosphorylation of A6-Tubulin by Protein Kinase C $\alpha$ Activates Motility of Human Breast Cells. J. Biol. Chem. 2009, 284, 17648-17656. [CrossRef]

79. De, S.; Tsimounis, A.; Chen, X.; Rotenberg, S.A. Phosphorylation of $\alpha$-Tubulin by Protein Kinase C Stimulates Microtubule Dynamics in Human Breast Cells. Cytoskeleton 2014, 71, 257-272. [CrossRef] [PubMed]

80. Liu, N.; Xiong, Y.; Ren, Y.; Zhang, L.; He, X.; Wang, X.; Liu, M.; Li, D.; Shui, W.; Zhou, J. Proteomic Profiling and Functional Characterization of Multiple Post-Translational Modifications of Tubulin. J. Proteome Res. 2015, 14, 3292-3304. [CrossRef] [PubMed]

81. Ji, S.; Kang, J.G.; Park, S.Y.; Lee, J.; Oh, Y.J.; Cho, J.W. O-GlcNAcylation of Tubulin Inhibits Its Polymerization. Amino Acids 2011, 40, 809-818. [CrossRef]

82. Janke, C.; Bulinski, J.C. Post-Translational Regulation of the Microtubule Cytoskeleton: Mechanisms and Functions. Nat. Rev. Mol. Cell Biol. 2011, 12,773-786. [CrossRef]

83. Van der Laan, S.; Lévêque, M.F.; Marcellin, G.; Vezenkov, L.; Lannay, Y.; Dubra, G.; Bompard, G.; Ovejero, S.; Urbach, S.; Burgess, A.; et al. Evolutionary Divergence of Enzymatic Mechanisms for Tubulin Detyrosination. Cell Rep. 2019, 29, 4159-4171. [CrossRef]

84. Paturle-Lafanechère, L.; Job, D.; Eddé, B.; Denoulet, P.; Van Dorsselaer, A.; Mazarguil, H.; Le Caer, J.P.; Wehland, J. Characterization of a Major Brain Tubulin Variant Which Cannot Be Tyrosinated. Biochemistry 1991, 30, 10523-10528. [CrossRef] [PubMed]

85. Rogowski, K.; van Dijk, J.; Magiera, M.M.; Bosc, C.; Deloulme, J.C.; Bosson, A.; Peris, L.; Gold, N.D.; Lacroix, B.; Grau, M.B.; et al. A Family of Protein-Deglutamylating Enzymes Associated with Neurodegeneration. Cell 2010, 143, 564-578. [CrossRef] [PubMed] 
86. Berezniuk, I.; Vu, H.T.; Lyons, P.J.; Sironi, J.J.; Xiao, H.; Burd, B.; Setou, M.; Angeletti, R.H.; Ikegami, K.; Fricker, L.D. Cytosolic Carboxypeptidase 1 Is Involved in Processing $\alpha$ - and $\beta$-Tubulin. J. Biol. Chem. 2012, 287, 6503-6517. [CrossRef]

87. Berezniuk, I.; Lyons, P.J.; Sironi, J.J.; Xiao, H.; Setou, M.; Angeletti, R.H.; Ikegami, K.; Fricker, L.D. Cytosolic Carboxypeptidase 5 Removes $\alpha$-And $\gamma$-Linked Glutamates from Tubulin. J. Biol. Chem. 2013, 288, 30445-30453. [CrossRef]

88. Ersfeld, K.; Wehland, J.; Plessmann, U.; Dodemont, H.; Gerke, V.; Weber, K. Characterization of the Tubulin-Tyrosine Ligase. J. Cell Biol. 1993, 120, 725-732. [CrossRef]

89. Prota, A.E.; Magiera, M.M.; Kuijpers, M.; Bargsten, K.; Frey, D.; Wieser, M.; Jaussi, R.; Hoogenraad, C.C.; Kammerer, R.A.; Janke, C.; et al. Structural Basis of Tubulin Tyrosination by Tubulin Tyrosine Ligase. J. Cell Biol. 2013, 200, 259-270. [CrossRef] [PubMed]

90. LeDizet, M.; Piperno, G. Cytoplasmic Microtubules Containing Acetylated $\alpha$-Tubulin in Chlamydomonas Reinhardtii: Spatial Arrangement and Properties. J. Cell Biol. 1986, 103, 13-22. [CrossRef] [PubMed]

91. Akella, J.S.; Wloga, D.; Kim, J.; Starostina, N.G.; Lyons-Abbott, S.; Morrissette, N.S.; Dougan, S.T.; Kipreos, E.T.; Gaertig, J. MEC-17 Is an $\alpha$-Tubulin Acetyltransferase. Nature 2010, 467, 218-222. [CrossRef]

92. Wloga, D.; Joachimiak, E.; Louka, P.; Gaertig, J. Posttranslational Modifications of Tubulin and Cilia. Cold Spring Harb. Perspect. Biol. 2017, 9. [CrossRef] [PubMed]

93. Shida, T.; Cueva, J.G.; Xu, Z.; Goodman, M.B.; Nachury, M.V. The Major Alpha-Tubulin K40 Acetyltransferase AlphaTAT1 Promotes Rapid Ciliogenesis and Efficient Mechanosensation. Proc. Natl. Acad. Sci. USA 2010, 107, 21517-21522. [CrossRef] [PubMed]

94. Hubbert, C.; Guardiola, A.; Shao, R.; Kawaguchi, Y.; Ito, A.; Nixon, A.; Yoshida, M.; Wang, X.F.; Yao, T.P. HDAC6 Is a Microtubule-Associated Deacetylase. Nature 2002, 417, 455-458. [CrossRef] [PubMed]

95. North, B.J.; Marshall, B.L.; Borra, M.T.; Denu, J.M.; Verdin, E. The Human Sir2 Ortholog, SIRT2, Is an NAD+-Dependent Tubulin Deacetylase. Mol. Cell 2003, 11, 437-444. [CrossRef]

96. Eshun-Wilson, L.; Zhang, R.; Portran, D.; Nachury, M.V.; Toso, D.B.; Löhr, T.; Vendruscolo, M.; Bonomi, M.; Fraser, J.S.; Nogales, E. Effects of $\alpha$-Tubulin Acetylation on Microtubule Structure and Stability. Proc. Natl. Acad. Sci. USA 2019, 116, 10366-10371. [CrossRef]

97. Portran, D.; Schaedel, L.; Xu, Z.; Théry, M.; Nachury, M.V. Tubulin Acetylation Protects Long-Lived Microtubules against Mechanical Ageing. Nat. Cell Biol. 2017, 19, 391-398. [CrossRef]

98. Xu, Z.; Schaedel, L.; Portran, D.; Aguilar, A.; Gaillard, J.; Peter Marinkovich, M.; Théry, M.; Nachury, M.V. Microtubules Acquire Resistance from Mechanical Breakage through Intralumenal Acetylation. Science 2017, 356, 328-332. [CrossRef]

99. Song, Y.; Kirkpatrick, L.L.; Schilling, A.B.; Helseth, D.L.; Chabot, N.; Keillor, J.W.; Johnson, G.V.W.; Brady, S.T. Transglutaminase and Polyamination of Tubulin: Posttranslational Modification for Stabilizing Axonal Microtubules. Neuron 2013, 78, 109-123. [CrossRef]

100. Goodson, H.V.; Jonasson, E.M. Microtubules and Microtubule-Associated Proteins. Cold Spring Harb. Perspect. Biol. 2018, 10. [CrossRef] [PubMed]

101. Manka, S.W.; Moores, C.A. Microtubule Structure by Cryo-EM: Snapshots of Dynamic Instability. Essays Biochem. 2018, 62, 737-751. [CrossRef] [PubMed]

102. Bodakuntla, S.; Jijumon, A.S.; Villablanca, C.; Gonzalez-Billault, C.; Janke, C. Microtubule-Associated Proteins: Structuring the Cytoskeleton. Trends Cell Biol. 2019, 29, 804-819. [CrossRef] [PubMed]

103. McNally, F.J.; Roll-Mecak, A. Microtubule-Severing Enzymes: From Cellular Functions to Molecular Mechanism. J. Cell Biol. 2018, 217, 4057-4069. [CrossRef]

104. Moore, A.; Wordeman, L. The Mechanism, Function and Regulation of Depolymerizing Kinesins during Mitosis. Trends Cell Biol. 2004, 14, 537-546. [CrossRef]

105. Moore, A.T.; Rankin, K.E.; Von Dassow, G.; Peris, L.; Wagenbach, M.; Ovechkina, Y.; Andrieux, A.; Job, D.; Wordeman, L. MCAK Associates with the Tips of Polymerizing Microtubules. J. Cell Biol. 2005, 169, 391-397. [CrossRef]

106. Reid, T.A.; Schuster, B.M.; Mann, B.J.; Keshavan Balchand, S.; Plooster, M.; Mcclellan, M.; Coombes, C.E.; Wadsworth, P.; Gardner, M.K. Suppression of Microtubule Assembly Kinetics by the Mitotic Protein TPX2. J. Cell Sci. 2016, 129, 1319-1328. [CrossRef]

107. Akhmanova, A.; Steinmetz, M.O. Microtubule +TIPs at a Glance. J. Cell Sci. 2010, 123, 3415-3419. [CrossRef] 
108. Akhmanova, A.; Steinmetz, M.O. Microtubule Minus-End Regulation at a Glance. J. Cell Sci. 2019, $132,1-7$. [CrossRef]

109. Cassimeris, L. The Oncoprotein 18/Stathmin Family of Microtubule Destabilizers. Curr. Opin. Cell Biol. 2002, 14, 18-24. [CrossRef]

110. Steinmetz, M.O. Structure and Thermodynamics of the Tubulin-Stathmin Interaction. J. Struct. Biol. 2007, 158, 137-147. [CrossRef] [PubMed]

111. Gupta, K.K.; Li, C.; Duan, A.; Alberico, E.O.; Kim, O.V.; Alber, M.S.; Goodson, H.V. Mechanism for the Catastrophe-Promoting Activity of the Microtubule Destabilizer Op18/Stathmin. Proc. Natl. Acad. Sci. USA 2013, 110, 20449-20454. [CrossRef] [PubMed]

112. Hendershott, M.C.; Vale, R.D. Regulation of Microtubule Minus-End Dynamics by CAMSAPs and Patronin. Proc. Natl. Acad. Sci. USA 2014, 111, 5860-5865. [CrossRef] [PubMed]

113. Cuveillier, C.; Delaroche, J.; Seggio, M.; Gory-Fauré, S.; Bosc, C.; Denarier, E.; Bacia, M.; Schoehn, G.; Mohrbach, H.; Kulić, I.; et al. MAP6 Is an Intraluminal Protein That Induces Neuronal Microtubules to Coil. Sci. Adv. 2020, 6. [CrossRef]

114. Cassimeris, L.; Spittle, C. Regulation of Microtubule-Associated Proteins. Int. Rev. Cytol. 2001, 210, $163-226$. [CrossRef]

115. Bieling, P.; Kandels-Lewis, S.; Telley, I.A.; Van Dijk, J.; Janke, C.; Surrey, T. CLIP-170 Tracks Growing Microtubule Ends by Dynamically Recognizing Composite EB1/Tubulinbinding Sites. J. Cell Biol. 2008, 183, 1223-1233. [CrossRef]

116. Peris, L.; Thery, M.; Fauré, J.; Saoudi, Y.; Lafanechère, L.; Chilton, J.K.; Gordon-Weeks, P.; Galjart, N.; Bornens, M.; Wordeman, L.; et al. Tubulin Tyrosination Is a Major Factor Affecting the Recruitment of CAP-Gly Proteins at Microtubule plus Ends. J. Cell Biol. 2006, 174, 839-849. [CrossRef]

117. Peris, L.; Wagenbach, M.; Lafanechère, L.; Brocard, J.; Moore, A.T.; Kozielski, F.; Job, D.; Wordeman, L.; Andrieux, A. Motor-Dependent Microtubule Disassembly Driven by Tubulin Tyrosination. J. Cell Biol. 2009, 185, 1159-1166. [CrossRef]

118. Bonnet, C.; Boucher, D.; Lazereg, S.; Pedrotti, B.; Islam, K.; Denoulet, P.; Larcher, J.C. Differential Binding Regulation of Microtubule-Associated Proteins MAP1A, MAP1B, and MAP2 by Tubulin Polyglutamylation. J. Biol. Chem. 2001, 276, 12839-12848. [CrossRef]

119. Boucher, D.; Larcher, J.C.; Gros, F.; Denoulet, P. Polyglutamylation of Tubulin as a Progressive Regulator of in Vitro Interactions between the Microtubule-Associated Protein Tau and Tubulin. Biochemistry 1994, 33, 12471-12477. [CrossRef] [PubMed]

120. Valenstein, M.L.; Roll-Mecak, A. Graded Control of Microtubule Severing by Tubulin Glutamylation. Cell 2016, 164, 911-921. [CrossRef] [PubMed]

121. Parker, A.L.; Teo, W.S.; McCarroll, J.A.; Kavallaris, M. An Emerging Role for Tubulin Isotypes in Modulating Cancer Biology and Chemotherapy Resistance. Int. J. Mol. Sci. 2017, 18, 1434. [CrossRef] [PubMed]

122. Naaz, F.; Haider, M.R.; Shafi, S.; Yar, M.S. Anti-Tubulin Agents of Natural Origin: Targeting Taxol, Vinca, and Colchicine Binding Domains. Eur. J. Med. Chem. 2019, 171, 310-331. [CrossRef] [PubMed]

123. Wani, M.C.; Taylor, H.L.; Wall, M.E.; Coggon, P.; Mcphail, A.T. Plant Antitumor Agents.VI.The Isolation and Structure of Taxol, a Novel Antileukemic and Antitumor Agent from Taxus Brevifolia2. J. Am. Chem. Soc. 1971, 93, 2325-2327. [CrossRef]

124. Rowinsky, E.K.; Cazenave, L.A.; Donehower, R.C. Taxol: A Novel Investigational Antimicrotubule Agent. J. Natl. Cancer Inst. 1990, 82, 1247-1259. [CrossRef]

125. Stanton, R.A.; Gernert, K.M.; Nettles, J.H.; Aneja, R. Drugs That Target Dynamic Microtubules: A New Molecular Perspective. Med. Res. Rev. 2011, 31, 443-481. [CrossRef]

126. Mukhtar, E.; Adhami, V.M.; Mukhtar, H. Targeting Microtubules by Natural Agents for Cancer Therapy. Mol. Cancer Ther. 2014, 13, 275-284. [CrossRef]

127. Bollag, D.M.; McQueney, P.A.; Zhu, J.; Hensens, O.; Koupal, L.; Liesch, J.; Goetz, M.; Lazarides, E.; Woods, C.M. Epothilones, a New Class of Microtubule-Stabilizing Agents with a Taxol-like Mechanism of Action. Cancer Res. 1995, 55, 2325-2333. 
128. Rugo, H.S.; Barry, W.T.; Moreno-Aspitia, A.; Lyss, A.P.; Cirrincione, C.; Leung, E.; Mayer, E.L.; Naughton, M.; Toppmeyer, D.; Carey, L.A.; et al. Randomized Phase III Trial of Paclitaxel Once per Week Compared with Nanoparticle Albumin-Bound Nab-Paclitaxel Once per Week or Ixabepilone with Bevacizumab as First-Line Chemotherapy for Locally Recurrent or Metastatic Breast Cancer: CALGB 40502/NCCTG N063H (Alliance). J. Clin. Oncol. 2015, 33, 2361-2369. [CrossRef]

129. McMeekin, S.; Dizon, D.; Barter, J.; Scambia, G.; Manzyuk, L.; Lisyanskaya, A.; Oaknin, A.; Ringuette, S.; Mukhopadhyay, P.; Rosenberg, J.; et al. Phase III Randomized Trial of Second-Line Ixabepilone versus Paclitaxel or Doxorubicin in Women with Advanced Endometrial Cancer. Gynecol. Oncol. 2015, 138, 18-23. [CrossRef]

130. Field, J.J.; Northcote, P.T.; Paterson, I.; Altmann, K.-H.; Díaz, J.F.; Miller, J.H. Zampanolide, a Microtubule-Stabilizing Agent, Is Active in Resistant Cancer Cells and Inhibits Cell Migration. Int. J. Mol. Sci. 2017, 18, 971. [CrossRef] [PubMed]

131. Wang, Y.; Yu, Y.; Li, G.-B.; Li, S.-A.; Wu, C.; Gigant, B.; Qin, W.; Chen, H.; Wu, Y.; Chen, Q.; et al. Mechanism of Microtubule Stabilization by Taccalonolide AJ. Nat. Commun. 2017. [CrossRef] [PubMed]

132. Choy, H. Taxanes in Combined Modality Therapy for Solid Tumors. Crit. Rev. Oncol. Hematol. 2001, 37, 237-247. [CrossRef]

133. Engels, F.K.; Sparreboom, A.; Mathot, R.A.A.; Verweij, J. Potential for Improvement of Docetaxel-Based Chemotherapy: A Pharmacological Review. Br. J. Cancer 2005, 93, 173-177. [CrossRef]

134. Larkin, J.M.G.; Kaye, S.B. Potential Clinical Applications of Epothilones: A Review of Phase II Studies. Ann. Oncol. Off. J. Eur. Soc. Med. Oncol. 2007, 18, 28-34. [CrossRef] [PubMed]

135. Paller, C.J.; Antonarakis, E.S. Cabazitaxel: A Novel Second-Line Treatment for Metastatic Castration-Resistant Prostate Cancer. Drug Des. Devel. Ther. 2011, 5, 117-124. [CrossRef] [PubMed]

136. Diéras, V.; Limentani, S.; Romieu, G.; Tubiana-Hulin, M.; Lortholary, A.; Kaufman, P.; Girre, V.; Besenval, M.; Valero, V. Phase II Multicenter Study of Larotaxel (XRP9881), a Novel Taxoid, in Patients with Metastatic Breast Cancer Who Previously Received Taxane-Based Therapy. Ann. Oncol. 2008, 19, 1255-1260. [CrossRef]

137. Sternberg, C.N.; Skoneczna, I.A.; Castellano, D.; Theodore, C.; Blais, N.; Voog, E.; Bellmunt, J.; Peters, F.; Le-Guennec, S.; Cerbone, L.; et al. Larotaxel with Cisplatin in the First-Line Treatment of Locally Advanced/Metastatic Urothelial Tract or Bladder Cancer: A Randomized, Active-Controlled, Phase III Trial (CILAB). Oncology 2013, 85, 208-215. [CrossRef]

138. Kellogg, E.H.; Hejab, N.M.A.; Howes, S.; Northcote, P.; Miller, J.H.; Díaz, J.F.; Downing, K.H.; Nogales, E. Insights into the Distinct Mechanisms of Action of Taxane and Non-Taxane Microtubule Stabilizers from Cryo-EM Structures. J. Mol. Biol. 2017, 429, 633-646. [CrossRef]

139. Prota, A.E.; Bargsten, K.; Zurwerra, D.; Field, J.J.; Díaz, J.F.; Altmann, K.-H.; Steinmetz, M.O. Molecular Mechanism of Action of Microtubule-Stabilizing Anticancer Agents. Science 2013, 339, 587-590. [CrossRef] [PubMed]

140. Mooberry, S.L.; Tien, G.; Hernandez, A.H.; Plubrukarn, A.; Davidson, B.S. Laulimalide and Isolaulimalide, New Paclitaxel-like Microtubule- Stabilizing Agents. Cancer Res. 1999, 59, 653-660. [PubMed]

141. West, L.M.; Northcote, P.T.; Battershill, C.N. Peloruside A: A Potent Cytotoxic Macrolide Isolated from the New Zealand Marine Sponge Mycale Sp. J. Org. Chem. 2000, 65, 445-449. [CrossRef] [PubMed]

142. Hood, K.A.; West, L.M.; Rouwé, B.; Northcote, P.T.; Berridge, M.V.; Wakefield, S.J.; Miller, J.H. Peloruside A, a Novel Antimitotic Agent with Paclitaxel-like Microtubule-Stabilizing Activity. Cancer Res. 2002, 62, 3356-3360.

143. Prota, A.E.; Bargsten, K.; Northcote, P.T.; Marsh, M.; Altmann, K.-H.; Miller, J.H.; Díaz, J.F.; Steinmetz, M.O. Structural Basis of Microtubule Stabilization by Laulimalide and Peloruside A. Angew. Chem. Int. Ed. Engl. 2014, 53, 1621-1625. [CrossRef]

144. Ganguly, A.; Cabral, F.; Yang, H.; Patel, K.D. Peloruside A Is a Microtubule-Stabilizing Agent with Exceptional Anti-Migratory Properties in Human Endothelial Cells. Oncoscience 2015, 2, 585-595. [CrossRef]

145. Kanakkanthara, A.; Rowe, M.R.; Field, J.J.; Northcote, P.T.; Teesdale-Spittle, P.H.; Miller, J.H. BI-Tubulin Mutations in the Laulimalide/Peloruside Binding Site Mediate Drug Sensitivity by Altering Drug-Tubulin Interactions and Microtubule Stability. Cancer Lett. 2015, 365, 251-260. [CrossRef]

146. Castro-Alvarez, A.; Pineda, O.; Vilarrasa, J. Further Insight into the Interactions of the Cytotoxic Macrolides Laulimalide and Peloruside A with Their Common Binding Site. ACS Omega 2018, 3, 1770-1782. [CrossRef] 
147. Johnson, I.S.; Wright, H.F.; Svoboda, G.H. Experimental Basis for Clinical Evaluation of Anti Tumor Principles Derived from Vinca-Rosea Linn. In Journal of Laboratory and Clinical Medicine; Mosby-Year Book Inc.: St Louis, MO, USA, 1959; Volume 54, p. 830.

148. Noble, R.L.; Beer, C.T.; Cutts, J.H. Further Biological Activities of Vincaleukoblastine-an Alkaloid Isolated from Vinca Rosea (L.). Biochem. Pharmacol. 1959, 1, 347-348. [CrossRef]

149. Liaw, T.; Chang, M.; Kavallaris, M. The Cytoskeleton as a Therapeutic Target in Childhood Acute Leukemia:Obstacles and Opportunities. Curr. Drug Targets 2007, 8, 739-749. [CrossRef] [PubMed]

150. Martino, E.; Casamassima, G.; Castiglione, S.; Cellupica, E.; Pantalone, S.; Papagni, F.; Rui, M.; Siciliano, A.M.; Collina, S. Vinca Alkaloids and Analogues as Anti-Cancer Agents: Looking Back, Peering Ahead. Bioorg. Med Chem. Lett. 2018, 28, 2816-2826. [CrossRef] [PubMed]

151. Gourmelon, C.; Bourien, H.; Augereau, P.; Patsouris, A.; Frenel, J.-S.; Campone, M. Vinflunine for the Treatment of Breast Cancer. Expert Opin. Pharmacother. 2016, 17, 1817-1823. [CrossRef] [PubMed]

152. Gidding, C.E.M.; Kellie, S.J.; Kamps, W.A.; De Graaf, S.S.N. Vincristine Revisited. Crit. Rev. Oncol. Hematol. 1999, 29, 267-287. [CrossRef]

153. Zhou, H.; Li, L.; Zhou, Y.; Han, Y. Syndrome of Inappropriate Antidiuretic Hormone Secretion from Concomitant Use of Itraconazole and Vindesine. J. Clin. Pharm. Ther. 2018, 43, 137-140. [CrossRef]

154. Kitagaki, J.; Shi, G.; Miyauchi, S.; Murakami, S.; Yang, Y. Cyclic Depsipeptides as Potential Cancer Therapeutics. Anti-Cancer Drugs 2015, 26, 259-271. [CrossRef]

155. Lichota, A.; Gwozdzinski, K. Anticancer Activity of Natural Compounds from Plant and Marine Environment. Int. J. Mol. Sci. 2018, 19, 3533. [CrossRef] [PubMed]

156. Altinoz, M.A.; Ozpinar, A.; Alturfan, E.E.; Elmaci, I. Vinorelbine's Anti-Tumor Actions May Depend on the Mitotic Apoptosis, Autophagy and Inflammation: Hypotheses with Implications for Chemo-Immunotherapy of Advanced Cancers and Pediatric Gliomas. J. Chemother. 2018, 30, 203-212. [CrossRef]

157. Bellmunt, J.; Théodore, C.; Demkov, T.; Komyakov, B.; Sengelov, L.; Daugaard, G.; Caty, A.; Carles, J.; Jagiello-Gruszfeld, A.; Karyakin, O.; et al. Phase III Trial of Vinflunine plus Best Supportive Care Compared with Best Supportive Care Alone after a Platinum-Containing Regimen in Patients with Advanced Transitional Cell Carcinoma of the Urothelial Tract. J. Clin. Oncol. 2009, 27, 4454-4461. [CrossRef]

158. Retz, M.; de Geeter, P.; Goebell, P.J.; Matz, U.; de Schultz, W.; Hegele, A. Vinflunine in Routine Clinical Practice for the Treatment of Advanced or Metastatic Urothelial Cell Carcinoma-Data from a Prospective, Multicenter Experience. BMC Cancer 2015, 15, 455. [CrossRef]

159. Assaraf, Y.G.; Leamon, C.P.; Reddy, J.A. The Folate Receptor as a Rational Therapeutic Target for Personalized Cancer Treatment. Drug Resist. Updates 2014, 17, 89-95. [CrossRef]

160. Twelves, C.; Cortes, J.; Vahdat, L.; Wanders, J.; Akerele, C.; Kaufman, P. Phase III Trials of Eribulin Mesylate (E7389) in Extensively Pretreated Patients with Locally Recurrent or Metastatic Breast Cancer. Clin. Breast Cancer 2010, 10, 160-163. [CrossRef] [PubMed]

161. Kumar, B.; Kumar, R.; Skvortsova, I.; Kumar, V. Mechanisms of Tubulin Binding Ligands to Target Cancer Cells: Updates on Their Therapeutic Potential and Clinical Trials. Curr. Cancer Drug Targets 2016, 17, 357-375. [CrossRef]

162. Akaiwa, M.; Martin, T.; Mendelsohn, B.A. Synthesis and Evaluation of Linear and Macrocyclic Dolastatin 10 Analogues Containing Pyrrolidine Ring Modifications. ACS Omega 2018, 3, 5212-5221. [CrossRef]

163. Gigant, B.; Wang, C.; Ravelli, R.B.G.; Roussi, F.; Steinmetz, M.O.; Curmi, P.A.; Sobel, A.; Knossow, M. Structural Basis for the Regulation of Tubulin by Vinblastine. Nature 2005, 435, 519-522. [CrossRef] [PubMed]

164. Doodhi, H.; Prota, A.E.; Rodríguez-García, R.; Xiao, H.; Custar, D.W.; Bargsten, K.; Katrukha, E.A.; Hilbert, M.; Hua, S.; Jiang, K.; et al. Termination of Protofilament Elongation by Eribulin Induces Lattice Defects That Promote Microtubule Catastrophes. Curr. Biol. 2016, 26, 1713-1721. [CrossRef] [PubMed]

165. Waight, A.B.; Bargsten, K.; Doronina, S.; Steinmetz, M.O.; Sussman, D.; Prota, A.E. Structural Basis of Microtubule Destabilization by Potent Auristatin Anti-Mitotics. PLoS ONE 2016, 11, e0160890. [CrossRef] [PubMed]

166. Alday, P.H.; Correia, J.J. Macromolecular Interaction of Halichondrin B Analogues Eribulin (E7389) and ER-076349 with Tubulin by Analytical Ultracentrifugation. Biochemistry 2009, 48, 7927-7938. [CrossRef]

167. Kupchan, S.M.; Komoda, Y.; Court, W.A.; Thomas, G.J.; Smith, R.M.; Karim, A.; Gilmore, C.J.; Haltiwanger, R.C.; Bryan, R.F. Maytansine, a Novel Antileukemic Ansa Macrolide from Maytenus Ovatus. J. Am. Chem. Soc. 1972, 94, 1354-1356. [CrossRef] [PubMed] 
168. Elez, E.; Gomez-Roca, C.; Soto Matos-Pita, A.; Argiles, G.; Valentin, T.; Coronado, C.; Iglesias, J.; Macarulla, T.; Betrian, S.; Fudio, S.; et al. First-in-Human Phase I Study of the Microtubule Inhibitor Plocabulin in Patients with Advanced Solid Tumors. Invest. New Drugs 2019, 37, 674-683. [CrossRef] [PubMed]

169. FDA Approves Ado-Trastuzumab Emtansine For Early Breast Cancer. Available online: https://www.fda.gov/drugs/resources-information-approved-drugs/fda-approves-ado-trastuzumabemtansine-early-breast-cancer (accessed on 2 August 2020).

170. Ozyukseler, D.T.; Basak, M.; Ay, S.; Koseoglu, A.; Arıcı, S.; Oyman, A.; Sürmeli, H.; Turan, M.; Turan, N.; Odabaş, H.; et al. Prognostic Factors of Ado-Trastuzumab Emtansine Treatment in Patients with Metastatic HER-2 Positive Breast Cancer. J. Oncol. Pharm. Pract. 2020. [CrossRef]

171. Prota, A.E.; Bargsten, K.; Diaz, J.F.; Marsh, M.; Cuevas, C.; Liniger, M.; Neuhaus, C.; Andreu, J.M.; Altmann, K.H.; Steinmetz, M.O. A New Tubulin-Binding Site and Pharmacophore for Microtubule-Destabilizing Anticancer Drugs. Proc. Natl. Acad. Sci. USA 2014, 111, 13817-13821. [CrossRef] [PubMed]

172. Chaudhuri, A.R.; Seetharamalu, P.; Schwarz, P.M.; Hausheer, F.H.; Ludueña, R.F. The Interaction of the B-Ring of Colchicine with Alpha-Tubulin: A Novel Footprinting Approach. J. Mol. Biol. 2000, 303, 679-692. [CrossRef] [PubMed]

173. Hastie, S.B. Interactions of Colchicine with Tubulin. Pharmacol. Ther. 1991, 51, 377-401. [CrossRef]

174. Kapoor, S.; Srivastava, S.; Panda, D. Indibulin Dampens Microtubule Dynamics and Produces Synergistic Antiproliferative Effect with Vinblastine in MCF-7 Cells: Implications in Cancer Chemotherapy. Sci. Rep. 2018, 8, 2-13. [CrossRef]

175. McLoughlin, E.C.; O’boyle, N.M. Colchicine-Binding Site Inhibitors from Chemistry to Clinic: A Review. Pharmaceuticals 2020, 13, 8. [CrossRef]

176. Patterson, J.C.; Joughin, B.A.; Prota, A.E.; Mühlethaler, T.; Jonas, O.H.; Whitman, M.A.; Varmeh, S.; Chen, S.; Balk, S.P.; Steinmetz, M.O.; et al. VISAGE Reveals a Targetable Mitotic Spindle Vulnerability in Cancer Cells. Cell Syst. 2019, 9, 74-92. [CrossRef]

177. Kawamura, T.; Kawatani, M.; Muroi, M.; Kondoh, Y.; Futamura, Y.; Aono, H.; Tanaka, M.; Honda, K.; Osada, H. Proteomic Profiling of Small-Molecule Inhibitors Reveals Dispensability of MTH1 for Cancer Cell Survival. Sci. Rep. 2016, 6. [CrossRef]

178. Gul, N.; Karlsson, J.; Tängemo, C.; Linsefors, S.; Tuyizere, S.; Perkins, R.; Ala, C.; Zou, Z.; Larsson, E.; Bergö, M.O.; et al. The MTH1 Inhibitor TH588 Is a Microtubule-Modulating Agent That Eliminates Cancer Cells by Activating the Mitotic Surveillance Pathway. Sci. Rep. 2019, 9. [CrossRef]

179. Gad, H.; Koolmeister, T.; Jemth, A.S.; Eshtad, S.; Jacques, S.A.; Ström, C.E.; Svensson, L.M.; Schultz, N.; Lundbäck, T.; Einarsdottir, B.O.; et al. MTH1 Inhibition Eradicates Cancer by Preventing Sanitation of the DNTP Pool. Nature 2014, 508, 215-221. [CrossRef]

180. Samaranayake, G.J.; Huynh, M.; Rai, P. MTH1 as a Chemotherapeutic Target: The Elephant in the Room. Cancers 2017, 9, 47. [CrossRef]

181. Ravelli, R.B.G.; Gigant, B.; Curmi, P.A.; Jourdain, I.; Lachkar, S.; Sobel, A.; Knossow, M. Insight into Tubulin Regulation from a Complex with Colchicine and a Stathmin-like Domain. Nature 2004, 428, 198-202. [CrossRef] [PubMed]

182. Massarotti, A.; Coluccia, A.; Silvestri, R.; Sorba, G.; Brancale, A. The Tubulin Colchicine Domain: A Molecular Modeling Perspective. ChemMedChem 2012, 7, 33-42. [CrossRef] [PubMed]

183. Kobayashi, S.; Tsuchiya, K.; Harada, T.; Nishide, M.; Kurokawa, T.; Nakagawa, T.; Shimada, N.; Kobayashi, K. Pironetin, a Novel Plant Growth Regulator Produced by Streptomyces Sp. NK10958. I. Taxonomy, Production, Isolation and Preliminary Characterization. J. Antibiot. 1994, 47, 697-702. [CrossRef] [PubMed]

184. Kobayashi, S.; Tsuchiya, K.; Kurokawa, T.; Nakagawa, T.; Shimada, N.; Iitaka, Y. Pironetin, a Novel Plant Growth Regulator Produced by Streptomyces Sp. Nk10958. II. Structural Elucidation. J. Antibiot. 1994, 47, 703-707. [CrossRef]

185. Prota, A.E.; Setter, J.; Waight, A.B.; Bargsten, K.; Murga, J.; Diaz, J.F.; Steinmetz, M.O. Pironetin Binds Covalently to ACys316 and Perturbs a Major Loop and Helix of $\alpha$-Tubulin to Inhibit Microtubule Formation. J. Mol. Biol. 2016, 428, 2981-2988. [CrossRef]

186. Yang, J.; Wang, Y.; Wang, T.; Jiang, J.; Botting, C.H.; Liu, H.; Chen, Q.; Yang, J.; Naismith, J.H.; Zhu, X.; et al. Pironetin Reacts Covalently with Cysteine-316 of $\alpha$-Tubulin to Destabilize Microtubule. Nat. Commun. 2016. [CrossRef] 
187. Coulup, S.K.; Georg, G.I. Revisiting Microtubule Targeting Agents: $\alpha$-Tubulin and the Pironetin Binding Site as Unexplored Targets for Cancer Therapeutics. Bioorg. Med. Chem. Lett. 2019, 29, 1865-1873. [CrossRef]

188. Sun, B.O.; Fang, Y.; Li, Z.; Chen, Z.; Xiang, J. Role of Cellular Cytoskeleton in Epithelial-Mesenchymal Transition Process during Cancer Progression. Biomed. Rep. 2015, 3, 603-610. [CrossRef] [PubMed]

189. Sinha, D.; Duijf, P.H.G.; Khanna, K.K. Mitotic Slippage: An Old Tale with a New Twist. Cell Cycle 2019, 18, 7-15. [CrossRef]

190. Kashyap, V.K.; Wang, Q.; Setua, S.; Nagesh, P.K.B.; Chauhan, N.; Kumari, S.; Chowdhury, P.; Miller, D.D.; Yallapu, M.M.; Li, W.; et al. Therapeutic Efficacy of a Novel BiII/BIV-Tubulin Inhibitor (VERU-111) in Pancreatic Cancer. J. Exp. Clin. Cancer Res. 2019, 38. [CrossRef]

191. Kavallaris, M.; Kuo, D.Y.S.; Burkhart, C.A.; Regl, D.L.; Norris, M.D.; Haber, M.; Horwitz, S.B. Taxol-Resistant Epithelial Ovarian Tumors Are Associated with Altered Expression of Specific $\beta$-Tubulin Isotypes. J. Clin. Invest. 1997, 100, 1282-1293. [CrossRef] [PubMed]

192. Ferguson, R.E.; Taylor, C.; Stanley, A.; Butler, E.; Joyce, A.; Harnden, P.; Patel, P.M.; Selby, P.J.; Banks, R.E. Resistance to the Tubulin-Binding Agents in Renal Cell Carcinoma: No Mutations in the Class I Beta-Tubulin Gene but Changes in Tubulin Isotype Protein Expression. Clin. Cancer Res. 2005, 11, 3439-3445. [CrossRef] [PubMed]

193. Yu, X.; Zhang, Y.; Wu, B.; Kurie, J.M.; Pertsemlidis, A. The MiR-195 Axis Regulates Chemoresistance through TUBB and Lung Cancer Progression through BIRC5. Mol. Ther. Oncolytics 2019, 14, 288-298. [CrossRef] [PubMed]

194. Ohishi, Y.; Oda, Y.; Basaki, Y.; Kobayashi, H.; Wake, N.; Kuwano, M.; Tsuneyoshi, M. Expression of Beta-Tubulin Isotypes in Human Primary Ovarian Carcinoma. Gynecol. Oncol. 2007, 105, 586-592. [CrossRef] [PubMed]

195. Nicoletti, M.I.; Valoti, G.; Giannakakou, P.; Zhan, Z.; Kim, J.H.; Lucchini, V.; Landoni, F.; Mayo, J.G.; Giavazzi, R.; Fojo, T. Expression of $\beta$-Tubulin Isotypes in Human Ovarian Carcinoma Xenografts and in a Sub-Panel of Human Cancer Cell Lines from the NCI-Anticancer Drug Screen: Correlation with Sensitivity to Microtubule Active Agents. Clin. Cancer Res. 2001, 7, 2912-2922. [PubMed]

196. Shalli, K.; Brown, I.; Heys, S.D.; Schofield, C.A. Alterations of B-tubulin Isotypes in Breast Cancer Cells Resistant to Docetaxel. FASEB J. 2005, 19, 1299-1301. [CrossRef]

197. Mi, R.; Pan, C.; Zhou, Y.; Liu, Y.; Jin, G.; Liu, F. Identification of the Metastasis Potential and Its Associated Genes in Melanoma Multinucleated Giant Cells Using the PHA-ECM830 Fusion Method. Oncol. Rep. 2016, 35, 211-218. [CrossRef]

198. Cullen, K.J.; Schumaker, L.; Nikitakis, N.; Goloubeva, O.; Tan, M.; Sarlis, N.J.; Haddad, R.I.; Posner, M.R. Beta-Tubulin-II Expression Strongly Predicts Outcome in Patients Receiving Induction Chemotherapy for Locally Advanced Squamous Carcinoma of the Head and Neck: A Companion Analysis of the TAX 324 Trial. J. Clin. Oncol. 2009, 27, 6222-6228. [CrossRef]

199. Lu, C.; Zhang, J.; He, S.; Wan, C.; Shan, A.; Wang, Y.; Yu, L.; Liu, G.; Chen, K.; Shi, J.; et al. Increased $\alpha$-Tubulin1b Expression Indicates Poor Prognosis and Resistance to Chemotherapy in Hepatocellular Carcinoma. Dig. Dis. Sci. 2013, 58, 2713-2720. [CrossRef]

200. Hasegawa, S.; Miyoshi, Y.; Egawa, C.; Ishitobi, M.; Taguchi, T.; Tamaki, Y.; Monden, M.; Noguchi, S. Prediction of Response to Docetaxel by Quantitative Analysis of Class I and III $\beta$-Tubulin Isotype MRNA Expression in Human Breast Cancers. Clin. Cancer Res. 2003, 9, 2992-2997.

201. Bernard-Marty, C.; Treilleux, I.; Dumontet, C.; Cardoso, F.; Fellous, A.; Gancberg, D.; Bissery, M.C.; Paesmans, M.; Larsimont, D.; Piccart, M.J.; et al. Microtuble-Associated Parameters as Predictive Markers of Docetaxel Activity in Advanced Breast Cancer Patients: Results of a Pilot Study. Clin. Breast Cancer 2002, 3, 341-345. [CrossRef] [PubMed]

202. Maahs, L.; Sanchez, B.E.; Gupta, N.; Van Harn, M.; Barrack, E.R.; Reddy, P.V.; Hwang, C. Class III $\beta$-Tubulin Expression as a Predictor of Docetaxel-Resistance in Metastatic Castrationresistant Prostate Cancer. PLoS ONE 2019, 14, e0222510. [CrossRef] [PubMed]

203. Ploussard, G.; Terry, S.; Maillé, P.; Allory, Y.; Sirab, N.; Kheuang, L.; Soyeux, P.; Nicolaiew, N.; Coppolani, E.; Paule, B.; et al. Class III $\beta$-Tubulin Expression Predicts Prostate Tumor Aggressiveness and Patient Response to Docetaxel-Based Chemotherapy. Cancer Res. 2010, 70, 9253-9264. [CrossRef] 
204. Öztop, S.; Işik, A.; Güner, G.; Gürdal, H.; Karabulut, E.; Yilmaz, E.; Akyol, A. Class III $\beta$-Tubulin Expression in Colorectal Neoplasms Is a Potential Predictive Biomarker for Paclitaxel Response. Anticancer Res. 2019, 39, 655-662. [CrossRef] [PubMed]

205. Miyata, Y.; Matsuo, T.; Nakamura, Y.; Yasuda, T.; Ohba, K.; Takehara, K.; Sakai, H. Expression of Class III Beta-Tubulin Predicts Prognosis in Patients with Cisplatin-Resistant Bladder Cancer Receiving Paclitaxel-Based Second-Line Chemotherapy. Anticancer Res. 2018, 38, 1629-1635. [CrossRef] [PubMed]

206. Höflmayer, D.; Öztürk, E.; Schroeder, C.; Hube-Magg, C.; Blessin, N.C.; Simon, R.; Lang, D.S.; Neubauer, E.; Göbel, C.; Heinrich, M.C.; et al. High Expression of Class III $\beta$-Tubulin in Upper Gastrointestinal Cancer Types. Oncol. Lett. 2018, 16, 7139-7145. [CrossRef] [PubMed]

207. Hwang, J.E.; Hong, J.Y.; Kim, K.; Kim, S.H.; Choi, W.Y.; Kim, M.J.; Jung, S.H.; Shim, H.J.; Bae, W.K.; Hwang, E.C.; et al. Class III $\beta$-Tubulin Is a Predictive Marker for Taxane-Based Chemotherapy in Recurrent and Metastatic Gastric Cancer. BMC Cancer 2013, 13, 2-9. [CrossRef]

208. Roque, D.M.; Bellone, S.; English, D.P.; Buza, N.; Cocco, E.; Gasparrini, S.; Bortolomai, I.; Ratner, E.; Silasi, D.A.; Azodi, M.; et al. Tubulin- $\beta$-III Overexpression by Uterine Serous Carcinomas Is a Marker for Poor Overall Survival after Platinum/Taxane Chemotherapy and Sensitivity to Epothilones. Cancer 2013, 119, 2582-2592. [CrossRef]

209. Narvi, E.; Jaakkola, K.; Winsel, S.; Oetken-Lindholm, C.; Halonen, P.; Kallio, L.; Kallio, M.J. Altered TUBB3 Expression Contributes to the Epothilone Response of Mitotic Cells. Br. J. Cancer 2013, 108, 82-90. [CrossRef]

210. Jiang, H.; Yu, X.M.; Zhou, X.M.; Wang, X.H.; Su, D. Correlation between Microtubule-Associated Gene Expression and Chemosensitivity of Patients with Stage II Non-Small Cell Lung Cancer. Exp. Ther. Med. 2013, 5, 1506-1510. [CrossRef]

211. Sève, P.; Isaac, S.; Trédan, O.; Souquet, P.J.; Pachéco, Y.; Pérol, M.; Lafanéchère, L.; Penet, A.; Peiller, E.L.; Dumontet, C. Expression of Class III $\beta$-Tubulin Is Predictive of Patient Outcome in Patients with Non-Small Cell Lung Cancer Receiving Vinorelbine-Based Chemotherapy. Clin. Cancer Res. 2005, 11, 5481-5486. [CrossRef]

212. Sève, P.; Lai, R.; Ding, K.; Winton, T.; Butts, C.; Mackey, J.; Dumontet, C.; Dabbagh, L.; Aviel-Ronen, S.; Seymour, L.; et al. Class III Beta-Tubulin Expression and Benefit from Adjuvant Cisplatin/Vinorelbine Chemotherapy in Operable Non-Small Cell Lung Cancer: Analysis of NCIC JBR.10. Clin. Cancer Res. 2007, 13, 994-999. [CrossRef] [PubMed]

213. Ferrandina, G.; Zannoni, G.F.; Martinelli, E.; Paglia, A.; Gallotta, V.; Mozzetti, S.; Scambia, G.; Ferlini, C. Class III $\beta$-Tubulin Overexpression Is a Marker of Poor Clinical Outcome in Advanced Ovarian Cancer Patients. Clin. Cancer Res. 2006, 12, 2774-2779. [CrossRef] [PubMed]

214. Aoki, D.; Oda, Y.; Hattori, S.; Taguchi, K.I.; Ohishi, Y.; Basaki, Y.; Oie, S.; Suzuki, N.; Kono, S.; Tsuneyoshi, M.; et al. Overexpression of Class III $\beta$-Tubulin Predicts Good Response to Taxane-Based Chemotherapy in Ovarian Clear Cell Adenocarcinoma. Clin. Cancer Res. 2009, 15, 1473-1480. [CrossRef] [PubMed]

215. Lebok, P.; Öztürk, M.; Heilenkötter, U.; Jaenicke, F.; Müller, V.; Paluchowski, P.; Geist, S.; Wilke, C.; Burandt, E.; Lebeau, A.; et al. High Levels of Class III $\beta$-Tubulin Expression Are Associated with Aggressive Tumor Features in Breast Cancer. Oncol. Lett. 2016, 11, 1987-1994. [CrossRef] [PubMed]

216. Nami, B.; Wang, Z. Genetics and Expression Profile of the Tubulin Gene Superfamily in Breast Cancer Subtypes and Its Relation to Taxane Resistance. Cancers 2018, 10, 274. [CrossRef] [PubMed]

217. Galmarini, C.M.; Treilleux, I.; Cardoso, F.; Bernard-Marty, C.; Durbecq, V.; Gancberg, D.; Bissery, M.C.; Paesmans, M.; Larsimont, D.; Piccart, M.J.; et al. Class III $\beta$-Tubulin Isotype Predicts Response in Advanced Breast Cancer Patients Randomly Treated Either with Single-Agent Doxorubicin or Docetaxel. Clin. Cancer Res. 2008, 14, 4511-4516. [CrossRef] [PubMed]

218. Akasaka, K.; Maesawa, C.; Shibazaki, M.; Maeda, F.; Takahashi, K.; Akasaka, T.; Masuda, T. Loss of Class III B-Tubulin Induced by Histone Deacetylation Is Associated with Chemosensitivity to Paclitaxel in Malignant Melanoma Cells. J. Invest. Dermatol. 2009, 129, 1516-1526. [CrossRef] [PubMed]

219. Christoph, D.C.; Kasper, S.; Gauler, T.C.; Loesch, C.; Engelhard, M.; Theegarten, D.; Poettgen, C.; Hepp, R.; Peglow, A.; Loewendick, H.; et al. Bv-Tubulin Expression Is Associated With Outcome Following Taxane-Based Chemotherapy in Non-Small Cell Lung Cancer. Br. J. Cancer 2012, 107, 823-830. [CrossRef]

220. Gan, P.P.; Kavallaris, M. Tubulin-Targeted Drug Action: Functional Significance of Class II and Class IVB $\beta$-Tubulin in Vinca Alkaloid Sensitivity. Cancer Res. 2008, 68, 9817-9824. [CrossRef] 
221. Yeh, I.-T.; Ludueña, R.F. The BetaII Isotype of Tubulin Is Present in the Cell Nuclei of a Variety of Cancers. Cell Motil. Cytoskelet. 2004, 57, 96-106. [CrossRef]

222. Ruksha, K.; Mezheyeuski, A.; Nerovnya, A.; Bich, T.; Tur, G.; Gorgun, J.; Luduena, R.; Portyanko, A. Over-Expression of BII-Tubulin and Especially Its Localization in Cell Nuclei Correlates with Poorer Outcomes in Colorectal Cancer. Cells 2019, 8, 25. [CrossRef] [PubMed]

223. Person, F.; Wilczak, W.; Hube-Magg, C.; Burdelski, C.; Möller-Koop, C.; Simon, R.; Noriega, M.; Sauter, G.; Steurer, S.; Burdak-Rothkamm, S.; et al. Prevalence of BIII-Tubulin (TUBB3) Expression in Human Normal Tissues and Cancers. Tumour Biol. 2017, 39. [CrossRef] [PubMed]

224. Paradiso, A.; Mangia, A.; Chiriatti, A.; Tommasi, S.; Zito, A.; Latorre, A.; Schittulli, F.; Lorusso, V. Biomarkers Predictive for Clinical Efficacy of Taxol-Based Chemotherapy in Advanced Breast Cancer. Ann. Oncol. 2005, 16, 14-19. [CrossRef] [PubMed]

225. Gan, P.P.; McCarroll, J.A.; Byrne, F.L.; Garner, J.; Kavallaris, M. Specific $\beta$-Tubulin Isotypes Can Functionally Enhance or Diminish Epothilone B Sensitivity in Non-Small Cell Lung Cancer Cells. PLoS ONE 2011, 6, e21717. [CrossRef]

226. Tsourlakis, M.C.; Weigand, P.; Grupp, K.; Kluth, M.; Steurer, S.; Schlomm, T.; Graefen, M.; Huland, H.; Salomon, G.; Steuber, T.; et al. BIII-Tubulin Overexpression Is an Independent Predictor of Prostate Cancer Progression Tightly Linked to ERG Fusion Status and PTEN Deletion. Am. J. Pathol. 2014, 184, 609-617. [CrossRef]

227. Hetland, T.E.; Hellesylt, E.; Flørenes, V.A.; Tropé, C.; Davidson, B.; Kærn, J. Class III $\beta$-Tubulin Expression in Advanced-Stage Serous Ovarian Carcinoma Effusions Is Associated with Poor Survival and Primary Chemoresistance. Hum. Pathol. 2011, 42, 1019-1026. [CrossRef]

228. Zhang, H.L.; Ruan, L.; Zheng, L.M.; Whyte, D.; Tzeng, C.M.; Zhou, X.W. Association between Class III $\beta$-Tubulin Expression and Response to Paclitaxel/Vinorebine-Based Chemotherapy for Non-Small Cell Lung Cancer: A Meta-Analysis. Lung Cancer 2012, 77, 9-15. [CrossRef]

229. Koh, Y.; Jang, B.; Han, S.-W.; Kim, T.-M.; Oh, D.-Y.; Lee, S.-H.; Kang, C.H.; Kim, D.-W.; Im, S.-A.; Chung, D.H.; et al. Expression of Class III Beta-Tubulin Correlates with Unfavorable Survival Outcome in Patients with Resected Non-Small Cell Lung Cancer. J. Thorac. Oncol. 2010, 5, 320-325. [CrossRef]

230. McCarroll, J.A.; Sharbeen, G.; Liu, J.; Youkhana, J.; Goldstein, D.; McCarthy, N.; Limbri, L.F.; Dischl, D.; Ceyhan, G.O.; Erkan, M.; et al. BIII-Tubulin: A Novel Mediator of Chemoresistance and Metastases in Pancreatic Cancer. Oncotarget 2015, 6, 2235-2249. [CrossRef]

231. Levallet, G.; Bergot, E.; Antoine, M.; Creveuil, C.; Santos, A.O.; Beau-Faller, M.; De Fraipont, F.; Brambilla, E.; Levallet, J.; Morin, F.; et al. High TUBB3 Expression, an Independent Prognostic Marker in Patients with Early Non-Small Cell Lung Cancer Treated by Preoperative Chemotherapy, Is Regulated by K-Ras Signaling Pathway. Mol. Cancer Ther. 2012, 11, 1203-1213. [CrossRef]

232. Nienstedt, J.C.; Gröbe, A.; Clauditz, T.; Simon, R.; Muenscher, A.; Knecht, R.; Sauter, G.; Moebius, C.; Blessmann, M.; Heiland, M.; et al. High-Level BIII-Tubulin Overexpression Occurs in Most Head and Neck Cancers but Is Unrelated to Clinical Outcome. J. Oral Pathol. Med. 2017, 46, 986-990. [CrossRef]

233. Reader, J.; Harper, A.K.; Legesse, T.; Staats, P.N.; Goloubeva, O.; Rao, G.G.; Fulton, A.; Roque, D.M. EP4 and Class III $\beta$-Tubulin Expression in Uterine Smooth Muscle Tumors: Implications for Prognosis and Treatment. Cancers 2019, 11, 1590. [CrossRef] [PubMed]

234. Sobierajska, K.; Wieczorek, K.; Ciszewski, W.M.; Sacewicz-Hofman, I.; Wawro, M.E.; Wiktorska, M.; Boncela, J.; Papiewska-Pajak, I.; Kwasniak, P.; Wyroba, E.; et al. $\beta$-III Tubulin Modulates the Behavior of Snail Overexpressed during the Epithelial-to-Mesenchymal Transition in Colon Cancer Cells. Biochim. Biophys. Acta Mol. Cell Res. 2016, 1863, 2221-2233. [CrossRef]

235. Radakovic, A.; Boger, D.L. High Expression of Class III $\beta$-Tubulin Has No Impact on Functional Cancer Cell Growth Inhibition of a Series of Key Vinblastine Analogs. Bioorg. Med. Chem. Lett. 2018, 28, 863-865. [CrossRef] [PubMed]

236. Sharbeen, G.; McCarroll, J.; Liu, J.; Youkhana, J.; Limbri, L.F.; Biankin, A.V.; Johns, A.; Kavallaris, M.; Goldstein, D.; Phillips, P.A. Delineating the Role of BIV-Tubulins in Pancreatic Cancer: BIVb-Tubulin Inhibition Sensitizes Pancreatic Cancer Cells to Vinca Alkaloids. Neoplasia 2016, 18, 753-764. [CrossRef] [PubMed] 
237. Sobierajska, K.; Ciszewski, W.M.; Wawro, M.E.; Wieczorek-Szukała, K.; Boncela, J.; Papiewska-Pajak, I.; Niewiarowska, J.; Kowalska, M.A. TUBB4B Downregulation Is Critical for Increasing Migration of Metastatic Colon Cancer Cells. Cells 2019, 8, 810. [CrossRef] [PubMed]

238. Chao, S.K.; Wang, Y.; Verdier-Pinard, P.; Yang, C.-P.H.; Liu, L.; Rodriguez-Gabin, A.; McDaid, H.M.; Horwitz, S.B. Characterization of a Human BV-Tubulin Antibody and Expression of This Isotype in Normal and Malignant Human Tissue. Cytoskeleton 2012, 69, 566-576. [CrossRef]

239. Mathew, D.; Wang, Y.; Van Arsdale, A.; Horwitz, S.B.; Mcdaid, H. Expression of BV-Tubulin in Secretory Cells of the Fallopian Tube Epithelium Marks Cellular Atypia. Int. J. Gynecol. Cancer 2018, 28, 363-370. [CrossRef] [PubMed]

240. Berrieman, H.K.; Lind, M.J.; Cawkwell, L. Do $\beta$-Tubulin Mutations Have a Role in Resistance to Chemotherapy? Lancet Oncology. 2004, 5, 158-164. [CrossRef]

241. Verrills, N.; Kavallaris, M. Improving the Targeting of Tubulin-Binding Agents: Lessons from Drug Resistance Studies. Curr. Pharm. Des. 2005, 11, 1719-1733. [CrossRef] [PubMed]

242. Huzil, J.T.; Chen, K.; Kurgan, L.; Tuszynski, J.A. The Roles of $\beta$-Tubulin Mutations and Isotype Expression in Acquired Drug Resistance. Cancer Inform. 2007, 3, 159-181. [CrossRef] [PubMed]

243. Wang, W.; Zhang, H.; Wang, X.; Patterson, J.; Winter, P.; Graham, K.; Ghosh, S.; Lee, J.C.; Katsetos, C.D.; Mackey, J.R.; et al. Novel Mutations Involving BI-, BIIA-, or BIVB-Tubulin Isotypes with Functional Resemblance to BIII-Tubulin in Breast Cancer. Protoplasma 2017, 254, 1163-1173. [CrossRef] [PubMed]

244. Magiera, M.M.; Singh, P.; Gadadhar, S.; Janke, C. Tubulin Posttranslational Modifications and Emerging Links to Human Disease. Cell 2018, 173, 1323-1327. [CrossRef] [PubMed]

245. Whipple, R.A.; Matrone, M.A.; Cho, E.H.; Balzer, E.M.; Vitolo, M.I.; Yoon, J.R.; Ioffe, O.B.; Tuttle, K.C.; Yang, J.; Martin, S.S. Epithelial-to-Mesenchymal Transition Promotes Tubulin Detyrosination and Microtentacles That Enhance Endothelial Engagement. Cancer Res. 2010, 70, 8127-8137. [CrossRef] [PubMed]

246. Soucek, K.; Kamaid, A.; Phung, A.D.; Kubala, L.; Bulinski, J.C.; Harper, R.W.; Eiserich, J.P. Normal and Prostate Cancer Cells Display Distinct Molecular Profiles of Alpha-Tubulin Posttranslational Modifications. Prostate 2006, 66, 954-965. [CrossRef] [PubMed]

247. Mialhe, A.; Lafanechère, L.; Job, D.; Treilleux, I.; Peloux, N.; Dumontet, C.; Brémond, A.; Panh, M.H.; Payan, R.; Wehland, J.; et al. Tubulin Detyrosination Is a Frequent Occurrence in Breast Cancers of Poor Prognosis. Cancer Res. 2001, 61, 5024-5027.

248. Kato, C.; Miyazaki, K.; Nakagawa, A.; Ohira, M.; Nakamura, Y.; Ozaki, T.; Imai, T.; Nakagawara, A. Low Expression of Human Tubulin Tyrosine Ligase and Suppressed Tubulin Tyrosination/Detyrosination Cycle Are Associated with Impaired Neuronal Differentiation in Neuroblastomas with Poor Prognosis. Int. J. Cancer 2004, 112, 365-375. [CrossRef]

249. Aillaud, C.; Bosc, C.; Peris, L.; Bosson, A.; Heemeryck, P.; Van Dijk, J.; Le Friec, J.; Boulan, B.; Vossier, F.; Sanman, L.E.; et al. Vasohibins/SVBP Are Tubulin Carboxypeptidases (TCPs) That Regulate Neuron Differentiation. Science 2017, 358, 1448-1453. [CrossRef]

250. Nieuwenhuis, J.; Adamopoulos, A.; Bleijerveld, O.B.; Mazouzi, A.; Stickel, E.; Celie, P.; Altelaar, M.; Knipscheer, P.; Perrakis, A.; Blomen, V.A.; et al. Vasohibins Encode Tubulin Detyrosinating Activity. Science 2017, 358, 1453-1456. [CrossRef]

251. Du, H.; Zhao, J.; Hai, L.; Wu, J.; Yi, H.; Shi, Y. The Roles of Vasohibin and Its Family Members: Beyond Angiogenesis Modulators. Cancer Biol. Ther. 2017, 18, 827-832. [CrossRef] [PubMed]

252. Zhang, B.; Wu, Z.; Xie, W.; Tian, D.; Chen, F.; Qin, C.; Du, Z.; Tang, G.; Gao, Q.; Qiu, X.; et al. The Expression of Vasohibin-1 and Its Prognostic Significance in Bladder Cancer. Exp. Ther. Med. 2017, 14, 3477-3484. [CrossRef] [PubMed]

253. Saba, N.F.; Magliocca, K.R.; Kim, S.; Muller, S.; Chen, Z.; Owonikoko, T.K.; Sarlis, N.J.; Eggers, C.; Phelan, V.; Grist, W.J.; et al. Acetylated Tubulin (AT) as a Prognostic Marker in Squamous Cell Carcinoma of the Head and Neck. Head Neck Pathol. 2014, 8, 66-72. [CrossRef] [PubMed]

254. Rai, A.; Kapoor, S.; Naaz, A.; Kumar Santra, M.; Panda, D. Enhanced Stability of Microtubules Contributes in the Development of Colchicine Resistance in MCF-7 Cells. Biochem. Pharmacol. 2017, 132, 38-47. [CrossRef] [PubMed]

255. Boggs, A.E.; Vitolo, M.I.; Whipple, R.A.; Charpentier, M.S.; Goloubeva, O.G.; Ioffe, O.B.; Tuttle, K.C.; Slovic, J.; Lu, Y.; Mills, G.B.; et al. $\alpha$-Tubulin Acetylation Elevated in Metastatic and Basal-like Breast Cancer Cells Promotes Microtentacle Formation, Adhesion, and Invasive Migration. Cancer Res. 2015, 75, 203-215. [CrossRef] 
256. Lee, C.C.; Cheng, Y.C.; Chang, C.Y.; Lin, C.M.; Chang, J.Y. Alpha-Tubulin Acetyltransferase/MEC-17 Regulates Cancer Cell Migration and Invasion through Epithelial-Mesenchymal Transition Suppression and Cell Polarity Disruption. Sci. Rep. 2018, 8, 1-15. [CrossRef]

257. Lagman, J.; Sayegh, P.; Lee, C.S.; Sulon, S.M.; Jacinto, A.Z.; Sok, V.; Peng, N.; Alp, D.; Benovic, J.L.; So, C.H. G Protein-Coupled Receptor Kinase 5 Modifies Cancer Cell Resistance to Paclitaxel. Mol. Cell. Biochem. 2019, 461, 103-118. [CrossRef]

258. Sakuma, T.; Uzawa, K.; Onda, T.; Shiiba, M.; Yokoe, H.; Shibahara, T.; Tanzawa, H. Aberrant Expression of Histone Deacetylase 6 in Oral Squamous Cell Carcinoma. Int. J. Oncol. 2006, 29, 117-124. [CrossRef]

259. Lee, Y.-S.; Lim, K.-H.; Guo, X.; Kawaguchi, Y.; Gao, Y.; Barrientos, T.; Ordentlich, P.; Wang, X.-F.; Counter, C.M.; Yao, T.-P. The Cytoplasmic Deacetylase HDAC6 Is Required for Efficient Oncogenic Tumorigenesis. Cancer Res. 2008, 68, 7561-7569. [CrossRef]

260. Gu, S.; Liu, Y.; Zhu, B.; Ding, K.; Yao, T.P.; Chen, F.; Zhan, L.; Xu, P.; Ehrlich, M.; Liang, T.; et al. Loss of $\alpha$-Tubulin Acetylation Is Associated with TGF- $\beta$-Induced Epithelial-Mesenchymal Transition. J. Biol. Chem. 2016, 291, 5396-5405. [CrossRef]

261. Banerjee, A. Increased Levels of Tyrosinated $\alpha-$, BIII-, and BIV-Tubulin Isotypes in Paclitaxel-Resistant MCF-7 Breast Cancer Cells. Biochem. Biophys. Res. Commun. 2002, 293, 598-601. [CrossRef]

262. Lafanechere, L.; Courtay-Cahen, C.; Kawakami, T.; Jacrot, M.; Rudiger, M.; Wehland, J.; Job, D.; Margolis, R.L. Suppression of Tubulin Tyrosine Ligase during Tumor Growth. J. Cell Sci. 1998, 111, 171-181. [PubMed]

263. Miller, L.M.; Menthena, A.; Chatterjee, C.; Verdier-Pinard, P.; Novikoff, P.M.; Horwitz, S.B.; Angeletti, R.H. Increased Levels of a Unique Post-Translationally Modified BIVb-Tubulin Isotype in Liver Cancer. Biochemistry 2008, 47, 7572-7582. [CrossRef] [PubMed]

264. Marcus, A.I.; Zhou, J.; O’Brate, A.; Hamel, E.; Wong, J.; Nivens, M.; El-Naggar, A.; Yao, T.P.; Khuri, F.R.; Giannakakou, P. The Synergistic Combination of the Farnesyl Transferase Inhibitor Lonafarnib and Paclitaxel Enhances Tubulin Acetylation and Requires a Functional Tubulin Deacetylase. Cancer Res. 2005, 65, 3883-3893. [CrossRef]

265. Zhang, Z.; Yamashita, H.; Toyama, T.; Sugiura, H.; Omoto, Y.; Ando, Y.; Mita, K.; Hamaguchi, M.; Hayashi, S.I.; Iwase, H. HDAC6 Expression Is Correlated with Better Survival in Breast Cancer. Clin. Cancer Res. 2004, 10, 6962-6968. [CrossRef] [PubMed]

266. Rocha, C.; Papon, L.; Cacheux, W.; Marques Sousa, P.; Lascano, V.; Tort, O.; Giordano, T.; Vacher, S.; Lemmers, B.; Mariani, P.; et al. Tubulin Glycylases Are Required for Primary Cilia, Control of Cell Proliferation and Tumor Development in Colon. EMBO J. 2014, 33, 2735. [CrossRef]

267. Markovsky, E.; de Stanchina, E.; Itzkowitz, A.; Haimovitz-Friedman, A.; Rotenberg, S.A. Phosphorylation State of Ser 165 in $\alpha$-Tubulin Is a Toggle Switch That Controls Proliferating Human Breast Tumors. Cell. Signal. 2018, 52, 74-82. [CrossRef] [PubMed]

268. Bhat, K.M.R.; Setaluri, V. Microtubule-Associated Proteins as Targets in Cancer Chemotherapy. Clin. Cancer Res. 2007, 13, 2849-2854. [CrossRef] [PubMed]

269. Fu, L.; Fu, H.; Zhou, L.; Xu, K.; Pang, Y.; Hu, K.; Wang, J.; Tian, L.; Liu, Y.; Wang, J.; et al. High Expression of MAP7 Predicts Adverse Prognosis in Young Patients with Cytogenetically Normal Acute Myeloid Leukemia. Sci. Rep. 2016, 6. [CrossRef]

270. Chien, T.-M.; Chan, T.-C.; Huang, S.K.-H.; Yeh, B.-W.; Li, W.-M.; Huang, C.-N.; Li, C.-C.; Wu, W.-J.; Li, C.-F. Role of Microtubule-Associated Protein $1 \mathrm{~b}$ in Urothelial Carcinoma: Overexpression Predicts Poor Prognosis. Cancers 2020, 12, 630. [CrossRef]

271. Xie, S.; Ogden, A.; Aneja, R.; Zhou, J. Microtubule-Binding Proteins as Promising Biomarkers of Paclitaxel Sensitivity in Cancer Chemotherapy. Med. Res. Rev. 2016, 36, 300-312. [CrossRef] [PubMed]

272. Melhems, R.F.; Zhu, X.-X.; Hailat, N.; Strahler, J.R.; Hanash, S.M. Characterization of the Gene for a Proliferation-Related Phosphoprotein (Oncoprotein 18) Expressed in High Amounts in Acute Leukemia. J. Biol. Chem. 1991, 266, 17747-17753.

273. Friedrich, B.; Grönberg, H.; Landström, M.; Gullberg, M.; Bergh, A. Differentiation-Stage Specific Expression of Oncoprotein 18 in Human and Rat Prostatic Adenocarcinoma. Prostate 1995, 27, 102-109. [CrossRef] [PubMed]

274. Price, D.K.; Ball, J.R.; Bahrani-Mostafavi, Z.; Vachris, J.C.; Kaufman, J.S.; Naumann, R.W.; Higgins, R.V.; Hall, J.B. The Phosphoprotein Op18/Stathmin Is Differentially Expressed in Ovarian Cancer. Cancer Invest. 2000, 18, 722-730. [CrossRef] [PubMed] 
275. Brattsand, G. Correlation of Oncoprotein 18/Stathmin Expression in Human Breast Cancer with Established Prognostic Factors. Br. J. Cancer 2000, 83, 311-318. [CrossRef]

276. Chen, G.; Wang, H.; Gharib, T.G.; Huang, C.C.; Thomas, D.G.; Shedden, K.A.; Kuick, R.; Taylor, J.M.G.; Kardia, S.L.R.; Misek, D.E.; et al. Overexpression of Oncoprotein 18 Correlates with Poor Differentiation in Lung Adenocarcinomas. Mol. Cell. Proteomics 2003, 2, 107-116. [CrossRef]

277. Ogino, S.; Nosho, K.; Baba, Y.; Kure, S.; Shima, K.; Irahara, N.; Toyoda, S.; Chen, L.; Kirkner, G.J.; Wolpin, B.M.; et al. A Cohort Study of STMN1 Expression in Colorectal Cancer: Body Mass Index and Prognosis. Am. J. Gastroenterol. 2009, 104, 2047-2056. [CrossRef]

278. Xi, W.; Rui, W.; Fang, L.; Ke, D.; Ping, G.; Hui-Zhong, Z. Expression of Stathmin/Op18 as a Signifcant Prognostic Factor for Cervical Carcinoma Patients. J Cancer Res. Clin. Oncol. 2009, 135, 837-846. [CrossRef]

279. Hsu, H.P.; Li, C.F.; Lee, S.W.; Wu, W.R.; Chen, T.J.; Chang, K.Y.; Liang, S.S.; Tsai, C.J.; Shiue, Y.L. Overexpression of Stathmin 1 Confers an Independent Prognostic Indicator in Nasopharyngeal Carcinoma. Tumor Biol. 2014, 35, 2619-2629. [CrossRef]

280. Reyes, H.D.; Miecznikowski, J.; Gonzalez-Bosquet, J.; Devor, E.J.; Zhang, Y.; Thiel, K.W.; Samuelson, M.I.; McDonald, M.; Stephan, J.M.; Hanjani, P.; et al. High Stathmin Expression Is a Marker for Poor Clinical Outcome in Endometrial Cancer: An NRG Oncology Group/Gynecologic Oncology Group Study. Gynecol. Oncol. 2017, 146, 247-253. [CrossRef]

281. Byrne, F.L.; Yang, L.; Phillips, P.A.; Hansford, L.M.; Fletcher, J.I.; Ormandy, C.J.; McCarroll, J.A.; Kavallaris, M. RNAi-Mediated Stathmin Suppression Reduces Lung Metastasis in an Orthotopic Neuroblastoma Mouse Model. Oncogene 2014, 33, 882-890. [CrossRef] [PubMed]

282. Alli, E.; Bash-Babula, J.; Yang, J.-M.; Hait, W.N. Effect of Stathmin on the Sensitivity to Antimicrotubule Drugs in Human Breast Cancer. Cancer Res. 2002, 62, 6864-6869. [PubMed]

283. Nishio, K.; Nakamura, T.; Koh, Y.; Kanzawa, F.; Tamura, T.; Saijo, N. Oncoprotein 18 Overexpression Increases the Sensitivity to Vindesine in the Human Lung Carcinoma Cells. Cancer 2001, 91, 1494-1499. [CrossRef]

284. Lin, X.; Liao, Y.; Xie, J.; Liu, S.; Su, L.; Zou, H. Op18/Stathmin Is Involved in the Resistance of Taxol Among Different Epithelial Carcinoma Cell Lines. Cancer Biother. Radiopharm. 2014, 29, 376-386. [CrossRef] [PubMed]

285. Lin, X.; Yu, T.; Zhang, L.; Chen, S.; Chen, X.; Liao, Y.; Long, D.; Shen, F. Silencing Op18/Stathmin by RNA Interference Promotes the Sensitivity of Nasopharyngeal Carcinoma Cells to Taxol and High-Grade Differentiation of Xenografted Tumours in Nude Mice. Basic Clin. Pharmacol. Toxicol. 2016, 119, 611-620. [CrossRef] [PubMed]

286. Alli, E.; Yang, J.M.; Ford, J.M.; Hait, W.N. Reversal of Stathmin-Mediated Resistance to Paclitaxel and Vinblastine in Human Breast Carcinoma Cells. Mol. Pharmacol. 2007, 71, 1233-1240. [CrossRef] [PubMed]

287. Wang, S.; Akhtar, J.; Wang, Z. Anti-STMN1 Therapy Improves Sensitivity to Antimicrotubule Drugs in Esophageal Squamous Cell Carcinoma. Tumor Biol. 2015, 36, 7797-7806. [CrossRef] [PubMed]

288. Feng, W.; Xiaoyan, X.; Xuan, Y.; Xiangke, L.; Zichang, Y.; Ran, Z.; Liuxing, W.; Qingxia, F. Silencing Stathmin-Modulating Efficiency of Chemotherapy for Esophageal Squamous Cell Cancer with Paclitaxel. Cancer Gene Ther. 2015, 22, 115-121. [CrossRef]

289. Shen, F.; Long, D.; Yu, T.; Chen, X.; Liao, Y.; Wu, Y.; Lin, X. Vinblastine Differs from Taxol as It Inhibits the Malignant Phenotypes of NSCLC Cells by Increasingthe Phosphorylation of Op18/Stathmin. Oncol. Rep. 2017, 37, 2481-2489. [CrossRef]

290. Sun, X.; Li, D.; Yang, Y.; Ren, Y.; Li, J.; Wang, Z.; Dong, B.; Liu, M.; Zhou, J. Microtubule-Binding Protein CLIP-170 Is a Mediator of Paclitaxel Sensitivity. J. Pathol. 2012, 226, 666-673. [CrossRef]

291. Luo, Y.; Li, D.; Ran, J.; Yan, B.; Chen, J.; Dong, X.; Liu, Z.; Liu, R.; Zhou, J.; Liu, M. End-Binding Protein 1 Stimulates Paclitaxel Sensitivity in Breast Cancer by Promoting Its Actions toward Microtubule Assembly and Stability. Protein Cell 2014, 5, 469-479. [CrossRef] [PubMed]

292. Masoumi, S.; Harisankar, A.; Gracias, A.; Bachinger, F.; Fufa, T.; Chandrasekar, G.; Gaunitz, F.; Walfridsson, J.; Kitambi, S. Drug Design, Development and Therapy Dovepress Understanding Cytoskeleton Regulators in Glioblastoma Multiforme for Therapy Design. Drug Des. Devel. Ther. 2016, 10, 2881-2897. [CrossRef] [PubMed]

293. Rouzier, R.; Rajan, R.; Wagner, P.; Hess, K.R.; Gold, D.L.; Stec, J.; Ayers, M.; Ross, J.S.; Zhang, P.; Buchholz, T.A.; et al. Microtubule-Associated Protein Tau: A Marker of Paclitaxel Sensitivity in Breast Cancer. Proc. Natl. Acad. Sci. USA 2005, 102, 8315-8320. [CrossRef] [PubMed] 
294. Smoter, M.; Bodnar, L.; Grala, B.; Stec, R.; Zieniuk, K.; Kozlowski, W.; Szczylik, C. Tau Protein as a Potential Predictive Marker in Epithelial Ovarian Cancer Patients Treated with Paclitaxel/Platinum First-Line Chemotherapy. J. Exp. Clin. Cancer Res. 2013, 32. [CrossRef]

295. Yamauchi, A.; Kobayashi, A.; Oikiri, H.; Yokoyama, Y. Functional Role of the Tau Protein in Epithelial Ovarian Cancer Cells. Reprod. Med. Biol. 2017, 16, 143-151. [CrossRef]

296. Veitia, R.; Bissery, M.C.; Martinez, C.; Fellous, A. Tau Expression in Model Adenocarcinomas Correlates with Docetaxel Sensitivity in Tumour-Bearing Mice. Br. J. Cancer 1998, 78, 871-877. [CrossRef]

297. Veitia, R.; David, S.; Barbier, P.; Vantard, M.; Gounon, P.; Bissery, M.C.; Fellous, A. Proteolysis of Microtubule Associated Protein 2 and Sensitivity of Pancreatic Tumours to Docetaxel. Br. J. Cancer 2000, 83, 544-549. [CrossRef]

298. Liu, Y.; Sturgis, C.D.; Grzybicki, D.M.; Jasnosz, K.M.; Olson, P.R.; Tong, M.; Dabbs, D.D.; Raab, S.S.; Silverman, J.F. Microtubule-Associated Protein-2: A New Sensitive and Specific Marker for Pulmonary Carcinoid Tumor and Small Cell Carcinoma. Mod. Pathol. 2001, 14, 880-885. [CrossRef]

299. Liu, Y.; Mangini, J.; Saad, R.; Silverman, A.R.; Abell, E.; Tung, M.Y.; Graner, S.R.; Silverman, J.F. Diagnostic Value of Microtubule-Associated Protein-2 in Merkel Cell Carcinoma. Appl. Immunohistochem. Mol. Morphol. 2003, 11, 326-329. [CrossRef]

300. Chen, J.Y.F.; Chang, Y.L.; Yu, Y.C.; Chao, C.C.; Kao, H.W.; Wu, C.T.; Lin, W.C.; Ko, J.Y.; Jou, Y.S. Specific Induction of the High-Molecular-Weight Microtubule-Associated Protein 2 (Hmw-MAP2) by Betel Quid Extract in Cultural Oral Keratinocytes: Clinical Implications in Betel Quid-Associated Oral Squamous Cell Carcinoma (OSCC). Carcinogenesis 2004, 25, 269-276. [CrossRef]

301. Song, Z.; He, C.D.; Sun, C.; Xu, Y.; Jin, X.; Zhang, Y.; Xiao, T.; Wang, Y.; Lu, P.; Jiang, Y.; et al. Increased Expression of MAP2 Inhibits Melanoma Cell Proliferation, Invasion and Tumor Growth in Vitro and in Vivo. Exp. Dermatol. 2010, 19, 958-964. [CrossRef] [PubMed]

302. Soltani, M.H.; Pichardo, R.; Song, Z.; Sangha, N.; Camacho, F.; Satyamoorthy, K.; Sangueza, O.P.; Setaluri, V. Microtubule-Associated Protein 2, a Marker of Neuronal Differentiation, Induces Mitotic Defects, Inhibits Growth of Melanoma Cells, and Predicts Metastatic Potential of Cutaneous Melanoma. Am. J. Pathol. 2005, 166, 1841-1850. [CrossRef]

303. Don, S.; Verrills, N.M.; Liaw, T.Y.E.; Liu, M.L.M.; Norris, M.D.; Haber, M.; Kavallaris, M. Neuronal-Associated Microtubule Proteins Class III $\beta$-Tubulin Ad MAP2c in Neuroblastoma: Role in Resistance to Microtubule-Targeted Drugs. Mol. Cancer Ther. 2004, 3, 1137-1146. [PubMed]

304. Kavallaris, M.; Tait, A.S.; Norris, M.D.; Haber, M.; Walsh, B.J.; He, L.; Horwitz, S.B. Multiple Microtubule Alterations Are Associated with Vinca Alkaloid Resistance in Human Leukemia Cells. Cancer Res. 2001, 61, 5803-5809.

305. Verrills, N.M.; Flemming, C.L.; Liu, M.; Ivery, M.T.; Cobon, G.S.; Norris, M.D.; Haber, M.; Kavallaris, M. Microtubule Alterations and Mutations Induced by Desoxyepothilone B: Implications for Drug-Target Interactions. Chem. Biol. 2003, 10, 597-607. [CrossRef]

306. Jiang, Y.Y.; Shang, L.; Shi, Z.Z.; Zhang, T.T.; Ma, S.; Lu, C.C.; Zhang, Y.; Hao, J.J.; Shi, C.; Shi, F.; et al. Microtubule-Associated Protein 4 Is an Important Regulator of Cell Invasion/Migration and a Potential Therapeutic Target in Esophageal Squamous Cell Carcinoma. Oncogene 2016, 35, 4846-4856. [CrossRef]

307. Xia, X.; He, C.; Wu, A.; Zhou, J.; Wu, J. Microtubule-Associated Protein 4 Is a Prognostic Factor and Promotes Tumor Progression in Lung Adenocarcinoma. Dis. Markers 2018, 2018. [CrossRef]

308. Zhang, R.; Li, L.; Chen, L.; Suo, Y.; Fan, J.; Zhang, S.; Wang, Y.; Gao, S.; Wang, Y. MAP7 Interacts with RC3H1 and Cooperatively Regulate Cell-Cycle Progression of Cervical Cancer Cells via Activating the NF-KB Signaling. Biochem. Biophys. Res. Commun. 2020, 527, 56-63. [CrossRef]

309. Zhang, L.; Liu, X.; Song, L.; Zhai, H.; Chang, C. MAP7 Promotes Migration and Invasion and Progression of Human Cervical Cancer through Modulating the Autophagy. Cancer Cell Int. 2020, 20. [CrossRef]

310. Gurunathan, S.; Kang, M.H.; Qasim, M.; Kim, J.H. Nanoparticle-Mediated Combination Therapy: Two-in-One Approach for Cancer. Int. J. Mol. Sci. 2018, 19, 3264. [CrossRef]

(C) 2020 by the authors. Licensee MDPI, Basel, Switzerland. This article is an open access article distributed under the terms and conditions of the Creative Commons Attribution (CC BY) license (http://creativecommons.org/licenses/by/4.0/). 